Global

\title{
Biogeochemical Cycles
}

\section{RESEARCH ARTICLE \\ 10.1029/2020GB006816 \\ Key Points: \\ - We developed and evaluated a wetland biogeochemical model (BRTSim-BAMS4) to quantify global wetland $\mathrm{CO}_{2}, \mathrm{CH}_{4}$, and $\mathrm{N}_{2} \mathrm{O}$ emissions and nutrient sequestration rates \\ - Modeling indicates that agricultural $\mathrm{N}$ fertilization and runoff increase $\mathrm{N}_{2} \mathrm{O}$ emissions by $13 \%$ in wetlands in the Northern Hemisphere \\ - At equal amount of $\mathrm{C}$ and $\mathrm{N}$ sequestered, fertilization leads to greater $\mathrm{C}$ and $\mathrm{N}$ gaseous emissions, while no differences were found for $\mathrm{S}$ sequestration}

Supporting Information:

Supporting Information may be found in the online version of this article.

Correspondence to:

C. Pasut,

c.pasut@sydney.edu.au

Citation:

Pasut, C., Tang, F. H. M., Hamilton, D., Riley, W. J., \& Maggi, F. (2021). Spatiotemporal assessment of GHG emissions and nutrient sequestration linked to agronutrient runoff in global wetlands. Global Biogeochemical Cycles, 35, e2020GB006816. https://doi. org/10.1029/2020GB006816

Received 1 SEP 2020

Accepted 24 FEB 2021
(C) 2021. American Geophysical Union. All Rights Reserved.
Spatiotemporal Assessment of GHG Emissions and Nutrient Sequestration Linked to Agronutrient Runoff in Global Wetlands

\author{
Chiara Pasut $^{1}$ (D) Fiona H. M. Tang ${ }^{1}$ (D), David Hamilton ${ }^{2}$ (D), William J. Riley ${ }^{3}$ (D) and \\ Federico Maggi $^{1}$ (D)
}

${ }^{1}$ Laboratory for Advanced Environmental Engineering Research, School of Civil Engineering, The University of Sydney, Sydney, NSW, Australia, ${ }^{2}$ Australian Rivers Institute, Griffith University, Nathan Campus, Nathan, QLD, Australia, ${ }^{3}$ Earth Sciences Division, Lawrence Berkeley National Laboratory, Berkeley, CA, USA

\begin{abstract}
Wetlands play a key role in regulating global greenhouse gas (GHG) emissions but anthropogenic impacts on nutrients may severely alter this balance. Recent assessments indicate that almost $22 \%$ of the global wetland area may be affected by agricultural runoff. In this work, we developed and applied a dynamic mechanistic reaction network model of soil organic matter linking the carbon (C), nitrogen $(\mathrm{N})$, and sulfur $(\mathrm{S})$ cycles at $0.5^{\circ} \times 0.5^{\circ}$ spatial resolution across the globe. The model was used to estimate GHG emissions and nutrient sequestration rates in wetlands, driven by environmental stressors including $\mathrm{N}, \mathrm{P}$, and S fertilization. Wetland annual GHG emissions are estimated to be $136 \pm 12.5 \mathrm{Tg}$ $\mathrm{C}-\mathrm{CH}_{4}, 589 \pm 45.8 \mathrm{Tg} \mathrm{C}-\mathrm{CO}_{2}$, and $0.3 \pm 0.04 \mathrm{Tg} \mathrm{N}-\mathrm{N}_{2} \mathrm{O}$; in contrast, $\mathrm{C}, \mathrm{N}$, and $\mathrm{S}$ annual sequestration rates are estimated to be $576 \pm 88.1 \mathrm{Tg} \mathrm{C}, 20 \pm 4.4 \mathrm{Tg} \mathrm{N}$, and $7.4 \pm 0.8 \mathrm{Tg}$ S, between 2000 and 2017. N fertilization inputs were responsible for $13 \% \mathrm{~N}_{2} \mathrm{O}$ emissions in wetlands in the Northern Hemisphere, while tropical wetlands were major reservoirs for $\mathrm{C}, \mathrm{N}$, and S. Temperature, net primary productivity, and methanogenic microorganisms exert the major control on GHG emissions. Wetland $\mathrm{CH}_{4}$ and $\mathrm{CO}_{2}$ emissions were found to have a hysteretic relationship with seasonal soil temperature, but not $\mathrm{N}_{2} \mathrm{O}$. A global-scale assessment is pivotal for best nutrient management practices, reducing nutrient losses, and controlling gas emissions.
\end{abstract}

\section{Introduction}

Significant and rapid changes in nutrient turnover and budget have occurred over the past century ( $\mathrm{Li}$ \& Bowman, 2001; Vitousek et al., 1997). Temperature, precipitation, soil weathering, microbial activity, and nutrient runoff control carbon $(\mathrm{C})$, nitrogen $(\mathrm{N})$, and sulfur $(\mathrm{S})$ availability and their turnover rates in wetlands (Matias et al., 2011; Whitehead, 2000). However, these dynamics have largely been overlooked in global-scale assessments, even though wetlands contribute globally between $25 \%$ and $30 \%$ of $\mathrm{CH}_{4}$ emissions (Saunois et al., 2020), store almost 30\% of the organic C (Lal, 2008), and have higher C soil content than forests and grasslands (Kayranli et al., 2010), while occupying only 7\% of the Earth's surface (Lehner \& Döll, 2004).

Unprecedented high temperatures in the northern latitudes have accelerated permafrost melting (Treat et al., 2016), leaving an unfrozen, active peat layer that remobilizes large amounts of $C$ and other nutrients into wetlands, and change their hydrological and biogeochemical functioning (Malone et al., 2013) resulting in higher $\mathrm{N}_{2} \mathrm{O}, \mathrm{CH}_{4}$, and $\mathrm{CO}_{2}$ emissions (Abbott \& Jones, 2015; Loiko et al., 2017). At lower latitudes, significant cropland expansion to meet the high global food and fiber demand has increased nonpoint nutrient pollution linked to fertilizer applications (Wagner et al., 2008). In addition, intense hydroclimatic fluctuations (i.e., prolonged droughts followed by sudden and severe floods) have affected watershed runoff resulting in nutrient-rich stormflow pulses into wetlands (Kaushal et al., 2014; Solomon, 2007) usually located at low elevation within the catchment (Were et al., 2019).

Changes in nutrient loads, whether anthropogenic or not, can interfere with the preexisting biogeochemical cycles within wetlands and significantly affect the gas emission quality and soil nutrient stocks. Anomalous concentrations of $\mathrm{N}$ or S can have inhibitory effects on the C cycle (Kaushal et al., 2010, 2011), such as $\mathrm{S}$ fertilization inhibiting $\mathrm{CH}_{4}$ emissions due to energetic preference of $\mathrm{SO}_{4}^{2-}$ reduction over $\mathrm{CH}_{4}$ genesis 
(Bronson et al., 1997; Gauci et al., 2004). A high rate of $\mathrm{N}$ fertilization increases $\mathrm{N}_{2} \mathrm{O}$ emissions (Bonnett et al., 2013; Burgin \& Groffman, 2012). However, a different response may occur in N-poor soil where an increase in $\mathrm{N}$ input may increase net primary productivity (NPP) and bioavailable substrates, in turn increasing $\mathrm{CH}_{4}$ emissions (Dise \& Verry, 2001). Over the long term, increases in NPP may also increase plant nutrient uptake, hence less $\mathrm{N}$ may be available to soil denitrifying bacteria (Mosier et al., 2002). Changes in nutrient inputs also affect microbial ecology, hence the nutrient turnover and storage. Excess nutrient inputs can increase rates of soil organic matter (SOM) decomposition and cause a shift toward wetlands as a net $\mathrm{C}$ source rather than a sink, and warming can also synergistically amplify this effect (Kaushal et al., 2014).

Many recent studies (Arora et al., 2018; Bloom et al., 2017; Hayman et al., 2014; L. Liu et al., 2020; Melton et al., 2013; Riley et al., 2011; Zhu et al., 2015) have investigated wetlands biogeochemistry coupled to hydroclimatic forcing, vegetation dynamics, soil properties, and soil biology to improve the $\mathrm{CH}_{4}$ budget assessment at regional and global scales. The Wetland $\mathrm{CH}_{4}$ Intercomparison of Model Projects (WETCHIMP; Melton et al., 2013; Wania et al., 2013) analyzed and compared the most advanced models available for global $\mathrm{CH}_{4}$ emissions using a common protocol for hydroclimatic variables next improved in Saunois et al. (2020). These projects can be considered the state-of-the-art in wetland modeling and highlight the strengths and weaknesses of current models. Besides the level of complexity used to describe the $\mathrm{C}$ cycle and climate feedbacks in each model, only a relatively small number of models incorporate multiple nutrient cycles, although they usually limit their descriptions to C and N (Saunois et al., 2020). Among those, Community Land Model 4 (CLM4Me; Riley et al., 2011), Dynamic land Ecosystem Model (DLEM; Tian et al., 2015; Tian, Melillo, et al., 2011; Tian, Xu, et al., 2011; Xu et al., 2010), ecosys (Chang et al., 2019; Grant, Mekonnen, \& Riley, 2019; Grant, Mekonnen, Riley, Arora, et al., 2019), and Sheffield Dynamic Global Vegetation Model (SDGVM; Beerling et al., 2011; Woodward et al., 1995) combine a global dynamic vegetation module, soil hydroclimatic changes, permafrost dynamics, land cover change, and agriculture management (e.g., fertilization, irrigation, and harvesting). However, each model solves each geographic grid cell independently; hence, no water runoff is explicitly accounted for (Wania et al., 2013), and only a very simplified version of the $\mathrm{N}$ cycle is represented. Therefore, the combined effects of global land use linked to hydroclimatic forces on global greenhouse gas (GHG) emissions and nutrient stocks are not fully described, resulting in model uncertainties. Addressing grid cell connectivity and feedback and the interrelationships between biologically mediated processes governing not only $\mathrm{C}$ and $\mathrm{N}$ but also $\mathrm{S}$ and $\mathrm{P}$ cycling will improve the understanding of watershed features.

The aim of this study was to investigate the relationship between multiple nutrient interactions (i.e., C, N, $\mathrm{S}$, and $\mathrm{P}$ ) and environmental forcing factors for wetland GHG emissions. We used a mechanistic nutrient biogeochemical model, Biotic and Abiotic Model for SOM-version 4 (BAMS4), in a dynamic solver, BRTSim, to describe in space and time the coupled ecohydrological and biogeochemical cycles over a global grid of $0.5^{\circ} \times 0.5^{\circ}$ resolution during the period 2000-2017. The mechanistic description of the wetland was coupled with a simplified runoff model that estimates agricultural runoff from the surrounding catchment to account for N, P, and S fertilizer inputs. Using BRTSim-BAMS4 we (1) report new estimates of wetland $\mathrm{CH}_{4}, \mathrm{~N}_{2} \mathrm{O}$, and $\mathrm{CO}_{2}$ emissions globally; (2) investigate and quantify nutrient sequestration rates in wetlands at different latitudes; (3) quantify the environmental factors that influence GHG emissions and nutrient sequestration; and (4) examine fertilization effects on GHG emission dynamics.

\section{Materials and Methods}

\subsection{C-N-S Reaction Network (BAMS4)}

The BAMS4 reaction network is a simplification of the SOM cycle described in Pasut et al. (2020) and elaborated from Riley et al. (2014), Tang et al. (2019), and Ceriotti et al. (2020). It consists of two organic polymer pools of PolyC (lignin and cellulose) and PolyCN (peptidoglycan), three organic monomer pools of MonoC, MonoCN, and MonoCS, representing the organic carbon, nitrogen, and sulfur, respectively, and two inorganic carbon molecules $\left(\mathrm{CH}_{4}\right.$ and $\left.\mathrm{CO}_{2}\right)$. The $\mathrm{C}$ cycle includes four microbial functional groups, three aerobic (fungi $F_{D E P}$, heterotrophic bacteria $B_{A E R}$, and methanotrophs $B_{M O B}$ ) and one anaerobic (methanogenic microbes $B_{M G B}$ ), which control the depolymerization, mineralization, $\mathrm{CH}_{4}$ oxidation, and $\mathrm{CH}_{4}$ genesis, respectively. The $\mathrm{C}$ cycle was coupled with the $\mathrm{N}$ and $\mathrm{S}$ cycles, which include nitrification, denitrification, nitrogen 
fixation, $\mathrm{S}$ pools reduction, $\mathrm{S}$ pools oxidation, and thiosulfate and sulfur trioxide disproportionation $\left(\mathrm{NH}_{3}\right.$ $\rightarrow \mathrm{NH}_{4}^{+} \rightarrow \mathrm{NO}_{2}^{-} \rightarrow \mathrm{NO}_{3}^{-} \rightarrow \mathrm{NO} \rightarrow \mathrm{N}_{2} \mathrm{O} \rightarrow \mathrm{N}_{2} \rightarrow \mathrm{NH}_{4}^{+}$, and $\mathrm{SO}_{4}^{2-} \rightarrow \mathrm{SO}_{3}^{2-} \rightarrow \mathrm{S}_{2} \mathrm{O}_{4}^{2-} \rightarrow \mathrm{S}_{0} \rightarrow \mathrm{HS}^{-}$, respectively). $\mathrm{NH}_{3}$ gas emissions can be large in agricultural system but typically very small in wetlands because the equilibrium reaction between $\mathrm{NH}_{4}^{+}$and $\mathrm{NH}_{3}(\mathrm{~g})$ is strongly directed toward $\mathrm{NH}_{4}^{+}$, resulting in very small wetland $\mathrm{NH}_{3}$ (g) exsolution and emission to the atmosphere, especially for low $\mathrm{NH}_{4}^{+}$concentration usually found in wetland (e.g., $10^{-5}$ or $10^{-6}$ ). Each $\mathrm{C}, \mathrm{N}$, and $\mathrm{S}$ pool can be present in aqueous, protected (e.g., on the mineral surface binding), or gaseous phase. Each reaction includes specific microbial functional groups (ammonia-oxidizing bacteria $B_{A O B}$, nitrite-oxidizing bacteria $B_{N O B}$, denitrifying bacteria $B_{D E N}$, sulfur reducing bacteria $B_{S r R B}$, thiosulfate- and sulfide-reducing bacteria $B_{T h S R B}$, sulfate-reducing bacteria $B_{S R B}$, thiosulfate and sulfide disproportioning bacteria $B_{S D B}$, and photolithoautotroph oxidizing bacteria $B_{S O B}$ ) described in detail in Pasut et al. (2020) and represented in Figure 1. The first two functional groups are aerobic, while the others are anaerobic. BAMS4 also represents a simplified $\mathrm{P}$ cycle that includes $\mathrm{PO}_{4}^{3-}$ production from MonoCN mineralization, $\mathrm{PO}_{4}^{3-}$ protection, and $\mathrm{PO}_{4}^{3-}$ plant uptake (R4, $\mathrm{R} 55$, and $\left.\mathrm{R} 32\right)$.

The microbial dynamics include $\mathrm{C}$ and $\mathrm{N}$ immobilization, growth, mortality, and necromass decomposition described by Michaelis-Menten-Monod kinetics. Less than 3\% of microbial biomass is composed by P and S (Paul, 2014); therefore, their immobilization was neglected. The biological response is controlled by temperature, $\mathrm{pH}$, water stress (Figure $\mathrm{S} 1$ ), $\mathrm{O}_{2}$ availability, and other stressors related to the competition for electron donors and acceptors, and inhibitory factors. SOM protection on the soil matrix is described as a kinetic reaction after Riley et al. (2014), while the protection of inorganic species is described at equilibrium. Plant nutrient uptake $\left(\mathrm{NH}_{4}^{+}, \mathrm{NO}_{3}^{-}, \mathrm{SO}_{4}^{2-}\right.$, and $\left.\mathrm{PO}_{4}^{3-}\right)$ is accounted for by $\mathrm{MM}$ kinetics, and $\mathrm{CH}_{4}$ is transported to the atmosphere by diffusion and plant uptake.

We used the NPP from the Moderate Resolution Imaging Spectroradiometer (MODIS) on NASA's Terra satellite (Imagery produced by the NASA Earth Observations team based on data provided by the MODIS Land Science Team) as a proxy of SOM input to the soil, and we used the C:N and C:S ratios of above and belowground litter quality to partition $\mathrm{C}, \mathrm{N}$, and $\mathrm{S}$ in soil (Table S7).

Tables S1-S6 summarize all the reactions and corresponding parameters for both biotic and abiotic processes used in BAMS4, which were derived from earlier estimation and validation (Maggi et al., 2008; Pasut et al., 2020; Riley et al., 2014) and are not expanded here.

\subsection{Data Description}

This study used georeferenced databases of dynamic and constant environmental variables at $0.5^{\circ} \times 0.5^{\circ}$ resolution globally. The dynamic quantities consist of monthly fractional wetland area (SWAMPS v3.2; Poulter et al., 2017; Schroeder et al., 2015), NPP (MODIS Land Science Team, 2019), evapotranspiration (Zhang et al., 2016), runoff, the 6-h Climatic Research Unit (CRU-TS 3.21) time series of precipitation, longwave and shortwave solar radiation, and atmospheric temperature, which were used to construct daily input data from 2000 to 2017. The constant quantities consist of the soil physical properties (i.e., porosity, bulk density, and soil texture; Hengl et al., 2017), soil hydrothermal properties (i.e., Brooks and Corey model parameters [Brooks \& Corey, 1964], permeability, heat capacity, and conductivity; Dai et al., 2013), equilibrium soil organic C (Hengl et al., 2017), land cover (MODIS - LC; Cover \& Change, 1999; Friedl \& Sulla-Menashe, 2015; Sulla-Menashe et al., 2019), N and P fertilization (Potter et al., 2011a, 2011b), and biogeochemical parameters. Kinetic parameters were not geographically distributed. Additionally, we created a global data set of S fertilization and four land cover-specific (grassland, forest, wetland, and tundra) maximum and average plant root density profiles (based on Canadell et al., 1996; Paul, 2014), methane plant efficiency emissions (based on Walter et al., 2001), nitrogen fixation rate (based on Paul, 2014), and C:N ratio of aboveground litter quality (based on Bréchet et al., 2017; Hättenschwiler \& Jørgensen, 2010; Paul, 2014; Pei et al., 2019; Rouifed et al., 2010; Snowdon et al., 2005), which are distributed as described in the Data Availability Statement and listed in Table S7.

The agricultural area surrounding the wetland was derived from the MODIS-IGBP land cover product (MODIS - LC; Cover \& Change, 1999; Friedl \& Sulla-Menashe, 2015; Sulla-Menashe et al., 2019). We calculated the long-term average area of both wetland and cropland from 2000 to 2017 and overlapped them 


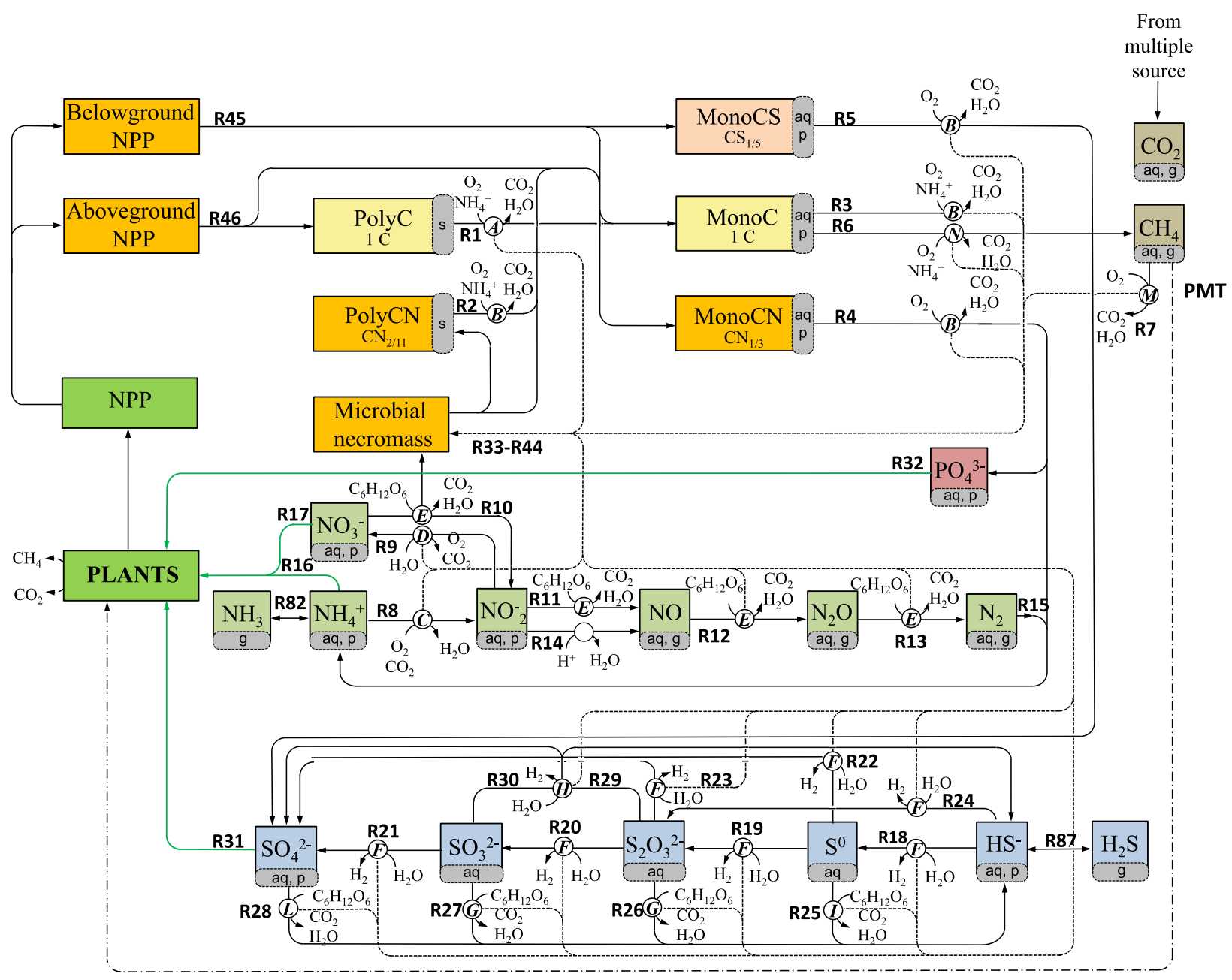

\begin{tabular}{|c|c|c|c|c|c|}
\hline $\begin{array}{l}\text { Organic C } \\
\text { compounds }\end{array}$ & $\begin{array}{l}\text { Inorganic C } \\
\text { compounds }\end{array}$ & $\begin{array}{l}\text { Inorganic P } \\
\text { compounds }\end{array}$ & $\begin{array}{l}\text { (A) Fungal } \\
\text { (B) AER bacteria }\end{array}$ & $\begin{array}{l}\text { (G) ThSRB bacteria } \\
\text { (H) SDB bacteria }\end{array}$ & $\begin{array}{l}\mathrm{C} \text { Chemical reaction } \\
\longrightarrow \text { Kinetic reaction }\end{array}$ \\
\hline $\begin{array}{l}\text { Organic CN } \\
\text { compounds }\end{array}$ & $\begin{array}{l}\text { Inorganic N } \\
\text { compounds }\end{array}$ & $\begin{array}{l}\text { aq. Compound phase } \\
\text { s. } \\
\text { p. (aqueous, solid, }\end{array}$ & (D) NOB bacteria & $\begin{array}{l}\text { (I) SrRB bacteria } \\
\text { (L) SRB bacteria }\end{array}$ & $\begin{array}{l}\text { Equilibrium reaction } \\
\text { Mortality }\end{array}$ \\
\hline $\begin{array}{l}\text { Organic CS } \\
\text { compounds }\end{array}$ & $\begin{array}{l}\text { Inorganic S } \\
\text { compounds }\end{array}$ & protected) & $\begin{array}{l}\text { (E) DEN bacteria } \\
(\text { F) SOB bacteria }\end{array}$ & $\begin{array}{l}\text { (d) MOB bacteria } \\
\text { (d) MGB bacteria }\end{array}$ & $\begin{array}{l}\text { Plant uptake } \\
\text { Aerenchyma transport }\end{array}$ \\
\hline
\end{tabular}

Figure 1. BAMS4 reaction network. RX identifies the reactions, which are expanded in Tables S1-S6 and are characterized by parameters earlier estimated and validated in Pasut et al. (2020). BAMS4, Biotic and Abiotic Model for SOM-version 4.

to identify the grid cells affected by agriculture, which were tagged across the entire simulation. The watershed discharge $Q$ was estimated following the Runoff Curve Number model (NRCS-CN) as Hong and Adler (2008):

$$
\begin{gathered}
Q=\frac{\left(P-I_{a}\right)^{2}}{P-I_{a}+S}, \\
S=\frac{25,400}{C N}-254,
\end{gathered}
$$

where $P$ is the precipitation, $I_{a}$ is the initial abstraction $\left(I_{a}=0.2 S\right), S$ is the potential retention, and $C N$ is the curve number estimated from hydrologic soil group characteristics (Figure S9), the class of land use, and 
the antecedent soil moisture condition (see supporting information and summary in Table S8). The flow direction was derived from the steepest down-slope gradient of a digital elevation map (Data Announcement 88-MGG-02, Digital relief of the Surface of the Earth. NOAA, National Geophysical Data Center, Boulder, $\mathrm{CO}, 1988)$. The nutrient concentration in the runoff was calculated as $30 \%$ of the total fertilizer inputs to account for crop nutrient uptake. We did not explicitly model crop dynamics in this work.

The details and reference for each database used in our modeling are summarized in Table S9.

\subsection{Computational Domain}

The computational domain involves about 25,000 grid cells describing wetlands, and neglects lakes, rivers, reservoirs, rice paddies (due to the lack of globally distributed data on the agricultural management), and saline estuaries and salt marshes (due to the high salt concentration that inhibits microbial metabolism, Poulter et al., 2017). From the original SWAMPS database (Poulter et al., 2017), we selected the grid cells where the maximum average wetland area fraction is greater than $5 \%$ to reduce computational effort and eliminate potential ephemeral wetlands (Figures S2a-S2c), and where the permafrost is less than $80 \%$ of the ground area (Brown et al., 2001) due to the lack of permafrost thawing modeling. The selected grid cells cover a wetland area of almost 5 million $\mathrm{km}^{2}$; which almost $22 \%$ is affected by agricultural runoff (Figure S2d). Each grid cell included a 2-m vertical profile divided over three soil layers of rootzone (30, 30, and $40 \mathrm{~cm}$ thickness), a soil layer of $100 \mathrm{~cm}$ below the rootzone, and four atmospheric layers $(30,30,40$, and $100 \mathrm{~cm}$ thickness) to allow for water ponding, and heat and gas exchange with the atmosphere.

Each grid cell was initialized with SOM concentrations estimated in the SoilGrids (Menne et al., 2012) and run for 250 years, relooping the same dynamic quantities of the 2000-2017 period to reach a statistical steady state in the biogeochemical reactions. The last 18 years were used for our analyses.

\subsection{BRTSim Solver}

BAMS4 was integrated in a general-purpose multiphase and multispecies bioreactive transport simulator, BRTSim-v4.0e solver, for the aqueous species advection and diffusion, gas diffusion, SOM protection in the soil matrix, and gas exsolution/dissolution, together with variably saturated soil and heat flow (Maggi, 2019). The vertical profile of each chemical and biological species in the soil was not imposed, neither over time nor over space, but emerged from multiple biologically mediated reactions in BAMS4. In this way, the system can respond to sudden environmental changes, particularly important for $\mathrm{pH}$ and $\mathrm{O}_{2}$ availability.

\subsection{Methods of Validation}

The simplified BAMS4 reaction network proposed here was first tested against the full-size BAMS3 network applied to a peatland in Michigan (Shannon \& White, 1994) to ensure equivalent outputs. Next, the monthly and long-term annual average land surface temperature of the topsoil (top $30 \mathrm{~cm}$ ) was assessed against the land surface temperature database of NOAA (top $5 \mathrm{~cm}$; Menne et al., 2012). The long-term average of modeled pH and SOC in the topsoil was assessed against the values in SoilGrids (Hengl et al., 2017). Modeled $\mathrm{CH}_{4}$ fluxes were benchmarked against the annual average field observations from 12 sites globally distributed (Table S10 data from FLUXNET2015 data set Pastorello et al. [2020]) and data for the Amazon catchment reported in Pangala et al. (2017). The global average annual $\mathrm{CH}_{4}$ emission was also compared to global modeling assessments (L. Liu et al., 2020) and top-down and bottom-up estimation from the Global Methane Budget 2000-2017 project related to wetland modeling in Saunois et al. (2020) (Table S10 and Figure S10). The $\mathrm{N}_{2} \mathrm{O}$ global emission was benchmarked against the DLEM global $\mathrm{N}_{2} \mathrm{O}$ estimation from terrestrial ecosystems in Tian et al. (2015). Average carbon sequestration rates were benchmarked against literature values in Mitsch et al. (2013), Villa and Bernal (2018), and Cheng et al. (2020). 


\subsection{Analyses}

Among all the outputs of BRTSim-BAMS4, the $\mathrm{C}, \mathrm{N}$, and $\mathrm{S}$ sequestration, and $\mathrm{CH}_{4}, \mathrm{CO}_{2}$, and $\mathrm{N}_{2} \mathrm{O}$ gas emissions were selected as target state variables in the analyses between 2000 and 2017. Emission rates were calculated as the variation of $\mathrm{CH}_{4}, \mathrm{CO}_{2}$, and $\mathrm{N}_{2} \mathrm{O}$ gaseous concentration across the four atmospheric nodes within a specific time interval. $\mathrm{CO}_{2}$ emissions include the $\mathrm{CO}_{2}$ produced during aerobic and anaerobic respiration, autotrophic $\mathrm{CH}_{4}$ oxidation, denitrification, $\mathrm{S}$ pool reductions, and $\mathrm{CH}_{4}$ oxidation during aerenchyma transport. $\mathrm{C}, \mathrm{N}$, and $\mathrm{S}$ sequestration rates were calculated as the total input (the above and belowground SOM input, $\mathrm{N}$ fixation, and $\mathrm{N}$ and $\mathrm{S}$ fertilizations) minus all the losses (gas emission, plant uptake of $\mathrm{N}$ and $\mathrm{S}$, and leaching below the root zone). Data are presented as average value \pm the standard deviation $\sigma\left(\sigma=\sqrt{\sum\left(x_{i}-\mu\right)^{2} / n}\right.$, where $x_{i}$ is a state variable, $\mu$ is its average, and $n$ is the sample size). Linear correlation coefficients were used to evaluate potential relationships between each GHG emission rate and wetland surface area. The lag time between the spike in gas emissions and the maximum area was calculated using cross-correlation analysis.

We grouped the wetlands according to the Köppen-Geiger (KG) climate classification (Köppen \& Geiger, 1930) to carry out a statistical analysis of the controlling stressors on GHG emissions and C, N, and S sequestration rates, and a dynamic analysis of the effect of fertilizers on GHG emissions and several controlling factors (temperature, SOM input, $B_{M G B}$, and $B_{D E N}$ ). For the first analysis, the Pearson coefficient was used to study the correlation of the forcing boundary conditions (, $\mathrm{N}$, and P fertilization, $\mathrm{N}$ fixation, the difference between precipitation and evapotranspiration, and SOM input), microbial functional group concentrations, soil variables (SOC, temperature, and $\mathrm{pH}$ ), and soil properties (porosity, hydraulic conductivity, root depth, soil bulk density, and $\mathrm{CH}_{4}$ plant uptake efficiency) against each target output for each climatic class. In this analysis, we accounted for the annual average of each variable between 2000 and 2017. The most relevant parameters resulting from this first stage were then analyzed seasonally by, comparing results with and without fertilizer input, and using the monthly average within each KG climatic class.

\section{Results}

\subsection{Model Validation}

Figure S3 shows that the simplified BAMS4 accurately capture the response of the full BAMS3 network for total $\mathrm{C}$ (TC), total $\mathrm{N}$ (TN), total $\mathrm{S}$ (TS) in soil, and the annual gas emissions of $\mathrm{CH}_{4}, \mathrm{~N}_{2} \mathrm{O}, \mathrm{CO}_{2}$, and $\mathrm{H}_{2} \mathrm{~S}$ $(R=0.995, p \leq 0.001)$. In addition, BAMS4 captured the monthly and long-term annual average land surface temperature data in Menne et al. (2012) (Figure S8a, $R=0.98$ ). The latter database reports only the first $5 \mathrm{~cm}$ of the topsoil, while our model refers to the first $30 \mathrm{~cm}$, which explains part of the mismatch. The benchmarking of $\mathrm{pH}$ and SOC in the topsoil against SoilGrids was satisfactory (Figures S8b and S8c, $R=0.72$ and $R=0.99$, respectively). Even though a background $\mathrm{H}^{+}$recovery reaction was included in BAMS4 to act as a buffer (R57-R58 in Table S6), the pH was overestimated in some range of expected values. The reason can be ascribed to nonlinear effects on $\mathrm{H}^{+}$production and consumption between the aerobic and anaerobic transition phases, and specific geochemistry of the soil, which are challenging to capture.

Benchmarking of $\mathrm{CH}_{4}$ emissions against field observations and the simulated global annual emission resulted in a relatively good match (scatter-plot in Figure 2a, Tables S10 and S11, and Figure S10, respectively). The simulated value of the Amazon catchment matched the top-down regional estimate $(32.0 \pm 4.2 \mathrm{Tg}$ $\mathrm{C}-\mathrm{CH}_{4}$ observed against the $29.3 \pm 1.6 \mathrm{Tg} \mathrm{C}-\mathrm{CH}_{4}$ simulated). Field measurements may include uncertainty, such as temporal gaps in the recording and limited numbers of years of data, hence hindering a direct comparison with the model output. Regional-scale measurements are not physically possible (Mekonnen et al., 2016), thus other global assessments from process-based and top-down models provide support to benchmark model outcomes. Our $\mathrm{N}_{2} \mathrm{O}$ global annual emission $\left(0.3 \pm 0.04 \mathrm{Tg} \mathrm{N}-\mathrm{N}_{2} \mathrm{O}\right)$ is lower than the value of Tian et al. (2015) ( $\left.0.95 \pm 0.04 \mathrm{Tg} \mathrm{N}-\mathrm{N}_{2} \mathrm{O}\right)$. This discrepancy may result from differences in the modeled $\mathrm{N}$ cycle; DLEM in Tian et al. (2015) represents a simplified version of the $\mathrm{N}$ cycles using an empirical equation to partition $\mathrm{N}$ gases into $\mathrm{N}_{2} \mathrm{O}, \mathrm{NO}$, and $\mathrm{N}_{2}$ as a function of porosity and volumetric water content, whereas BRTSim-BAMS4 attempts to account for other environmental factors, such as an explicit microbial dynamics, $\mathrm{O}_{2}$, and $\mathrm{pH}$. 

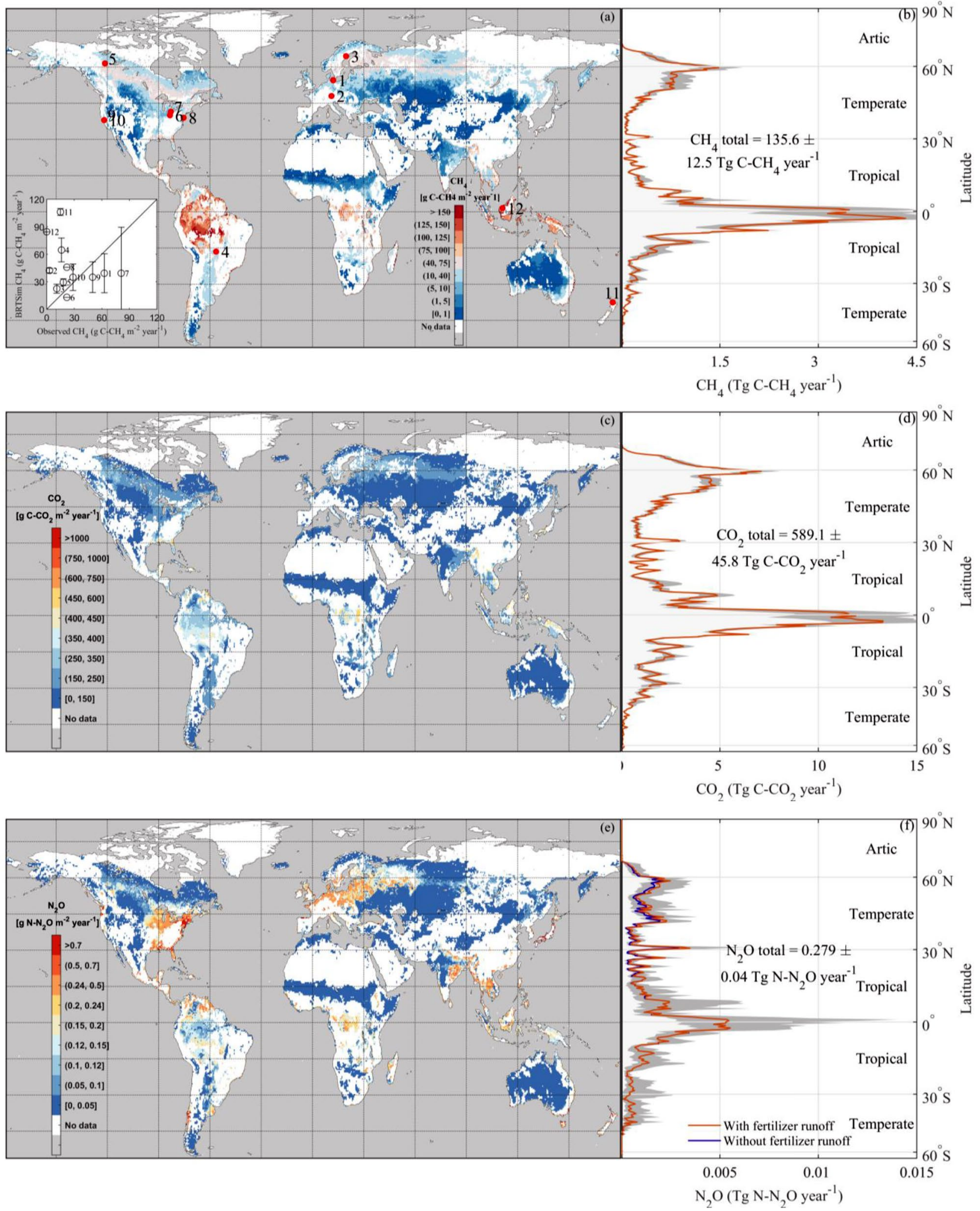

Figure 2. Global averages and isolatitude sums emission (at $0.5^{\circ}$ latitude) of (a and b) $\mathrm{CH}_{4}$, (c and d) $\mathrm{CO}_{2}$, and (e and f) $\mathrm{N}_{2} \mathrm{O}$ emissions. In (a, c, and d), the average emission is normalized by the average wetland area. Light-gray shaded areas in (b, $d$, and f) represent the standard deviations of the isolatitude sums between 2000 and 2017. Panel (f) compares the assessments with and without the effect of fertilizer runoff (no significant effect on $\mathrm{CH}_{4}$ and $\mathrm{CO}_{2}$ emissionsdata not shown). Inset in (a) shows the simulated $\mathrm{CH}_{4}$ emissions against 12 field observations. 


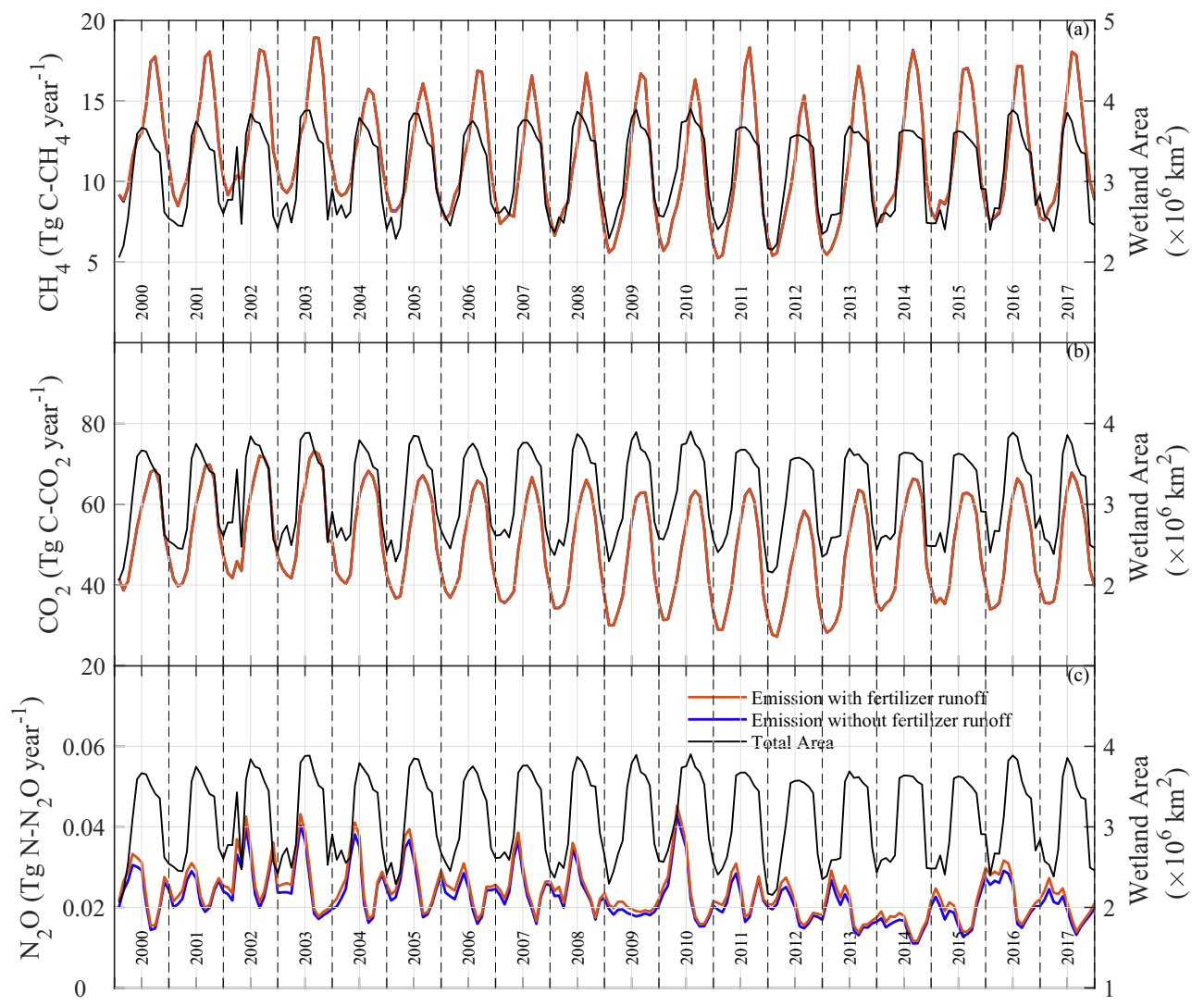

Figure 3. Global monthly average wetland area (black line in a-c), (a) $\mathrm{CH}_{4}$, (b) $\mathrm{CO}_{2}$, and (c) $\mathrm{N}_{2} \mathrm{O}$ emissions between 2008 and 2017. Panel (c) compares the assessments with and without the effect of fertilizer input (blue line).

The reader can find the benchmark for temperature, $\mathrm{pH}$, and SOC (Figures S8a-S8c), the corresponding anomaly maps (Figures S4, S6, and S7), as well as benchmarking samples for the seasonal temperature in 20 random grid cells over time (Figure S5).

\section{2. $\mathrm{CH}_{4}, \mathrm{CO}_{2}$, and $\mathrm{N}_{2} \mathrm{O}$ Emissions}

The estimated annual global average $\mathrm{CH}_{4}, \mathrm{CO}_{2}$, and $\mathrm{N}_{2} \mathrm{O}$ emissions were $135.6 \pm 12.5 \mathrm{Tg} \mathrm{C}-\mathrm{CH}_{4}$, $589.1 \pm 45.8 \mathrm{Tg} \mathrm{C}-\mathrm{CO}_{2}$, and $0.3 \pm 0.04 \mathrm{Tg} \mathrm{N}-\mathrm{N}_{2} \mathrm{O}$, respectively, between 2000 and 2017. A significantly high correlation exists between global monthly wetland $\mathrm{CH}_{4}$ and $\mathrm{CO}_{2}$ emissions $(R=0.98$ and $p \leq 0.01)$, while no correlation links $\mathrm{CH}_{4}$ and $\mathrm{N}_{2} \mathrm{O}$ emissions $(R=-0.08$ and $p \geq 0.01)$, indicating that different environmental factors influence the $\mathrm{N}_{2} \mathrm{O}$ emissions (Figure 3). In the long term, all GHG emissions and the wetland area show a seasonal pattern (Figures 3a-3c) that follows the temperature change in the Northern Hemisphere, which causes the most significant seasonal changes in wetland area due to snow melting and runoff (Figures $\mathrm{S} 2 \mathrm{a}-\mathrm{S} 2 \mathrm{c}) . \mathrm{CH}_{4}$ and $\mathrm{CO}_{2}$ peak between June and August, approximately 4-6 weeks after the peak in wetland area, suggesting a lag time between the optimal biomass response and the rise in water table and temperature. In contrast, the spike in $\mathrm{N}_{2} \mathrm{O}$ emissions occurs about 6 weeks before the peak in area, due to a more prompt response of denitrifying bacteria to temperature (optimum between $13^{\circ} \mathrm{C}$ and $37^{\circ} \mathrm{C}$ rather than $20^{\circ} \mathrm{C}$ and $37^{\circ} \mathrm{C}$ of $B_{M G B}$ ), a faster reaction rate, and less $\mathrm{O}_{2}$ inhibition for $B_{D E N}$.

Spatially, the tropical areas in the Amazon, central Africa, and southeast Asia were the principal hot-spots

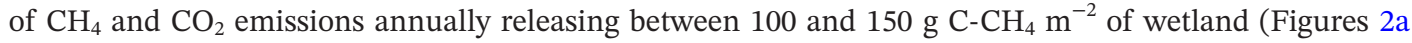
and $2 \mathrm{c}$ ) and 350 and $750 \mathrm{~g} \mathrm{C}-\mathrm{CO}_{2} \mathrm{~m}^{-2}$ (Figures $2 \mathrm{~b}$ and $2 \mathrm{~d}$ ), respectively. The northern latitude regions (e.g., Canada, Alaska, and north Russia) show the second highest emissions due to the prevalence of summer wetlands (Figures S2a-S2c) and the high SOM input from the peatland and bog vegetation, despite the low winter temperature. In contrast, southern latitudes (e.g., south Australia, Patagonia), Sub-Sahara, and 
central Europe show significantly lower emissions, on average 1-40 g C- $\mathrm{CH}_{4} \mathrm{~m}^{-2}$ year ${ }^{-1}$, and $150-350 \mathrm{~g}$ C- $\mathrm{CO}_{2} \mathrm{~m}^{-2}$ year $^{-1}$, respectively.

$\mathrm{N}_{2} \mathrm{O}$ emissions follow a spatial distribution directly linked to $\mathrm{N}$ fertilization; hence, $\mathrm{N}_{2} \mathrm{O}$ gases are greater for those areas where wetlands and croplands are in proximity, mostly in the north temperate regions and north-east India (yellow grid cells in Figure S1d). Here, the annual average emission is between 0.2 and $0.5 \mathrm{~g} \mathrm{~N}^{-\mathrm{N}_{2}} \mathrm{O} \mathrm{m}^{-2}$ year, which contributes to the spike in emissions for a given latitude range. Tropical areas have relatively high emissions as well, on average between 0.12 and $0.2 \mathrm{~g} \mathrm{~N}^{-\mathrm{N}_{2}} \mathrm{O} \mathrm{m}^{-2}$ year $^{-1}$, and there is a close relationship between $\mathrm{SOM}$ input and $\mathrm{N}_{2} \mathrm{O}$ emissions for areas not affected by $\mathrm{N}$ fertilization. In contrast, lower emissions occur in wetlands in Australia and Sub-Saharian regions, which are characterized by sparse vegetation and negligible runoff from agriculture, releasing $\leq 0.05{\mathrm{~g} \mathrm{~N}-\mathrm{N}_{2} \mathrm{O} \mathrm{m}}^{-2}$ year $^{-1}$.

A simulation conducted without fertilizer input (blue line, Figure 2f) shows that $\mathrm{N}_{2} \mathrm{O}$ emissions in the Southern Hemisphere are not significantly affected by $\mathrm{N}$ fertilization, while the overall emission is almost $13 \%$ higher than with fertilization runoff between $60^{\circ} \mathrm{N}$ and $10^{\circ} \mathrm{N}$. Comparing the two simulations (Figure $3 \mathrm{c}$ ), $\mathrm{N}_{2} \mathrm{O}$ emissions without fertilization follow the same seasonality as those with fertilization; however, the peak is significantly lower.

\subsection{Nutrient Sequestration Rates}

Globally, the average $\mathrm{C}, \mathrm{N}$, and $\mathrm{S}$ sequestration rates are $120.5 \pm 122.5 \mathrm{~g} \mathrm{C} \mathrm{m}^{-2}$ of wetland year ${ }^{-1}, 3.75 \pm 5.6 \mathrm{~g}$ $\mathrm{N} \mathrm{m}^{-2}$ year $^{-1}$, and $0.98 \pm 2.05 \mathrm{~g} \mathrm{~S} \mathrm{~m}^{-2}$ year $^{-1}$. The tropics have the highest sequestration rates of $\mathrm{C}, \mathrm{N}$, and $\mathrm{S}$; on average, $273.6 \mathrm{~g} \mathrm{C} \mathrm{m}^{-2}$ year $^{-1}, 11.4 \mathrm{~g} \mathrm{~N} \mathrm{~m}^{-2}$ year $^{-1}$, and $4.2 \mathrm{~g} \mathrm{~S} \mathrm{~m}^{-2}$ year $^{-1}$ (Figures 4a, 4d, and $4 \mathrm{~g}$ and Table 1). Carbon sequestration was also very high in peatland regions in northern latitudes (continental class [Dfc]), ranging between 200 and $400 \mathrm{~g} \mathrm{C} \mathrm{m}^{-2}$ of wetland year ${ }^{-1}$. Negative $\mathrm{C}$ sequestration rates (losses from soil) are observed mainly in the Sub-Sahara Desert, while negative $\mathrm{N}$ sequestration rates are found in northern Tibet. In contrast, negative $\mathrm{S}$ sequestration rates are globally distributed without a clear pattern. We further compared each nutrient sequestration rate with the corresponding total gas emissions, where each square in Figures 4c, 4f, and 4i represents the bin average of $10 \mathrm{~g} \mathrm{C} \mathrm{m}^{-2}$ year $^{-1}, 1 \mathrm{~g} \mathrm{~N} \mathrm{~m}^{-2}$ year $^{-1}$, and $1 \mathrm{~g} \mathrm{~S} \mathrm{~m}^{-2}$ year $^{-1}$ increments. We found that an increase in $\mathrm{C}$ sequestration corresponds to an increase in $\mathrm{C}$ emission (the sum of $\mathrm{CH}_{4}$ and $\mathrm{CO}_{2}$ ), up to a maximum of $350 \mathrm{~g} \mathrm{C} \mathrm{m}^{-2}$ year ${ }^{-1}$, after which the emissions slightly decrease and stabilize between 700 and $400 \mathrm{~g} \mathrm{C} \mathrm{m}^{-2}$ year $^{-1}$. Wetlands with high sequestration to emission ratios are located in the Southern Hemisphere (Amazon catchment, Malaysia, Indonesia, east Australia, and New Zealand) and are characterized by high SOM input and $\mathrm{pH} \leq 6$, which slows anaerobic reaction rates. We found the same patterns between $\mathrm{N}$ sequestration and total $\mathrm{N}$ emissions (corresponding to the sum of $\mathrm{NO}, \mathrm{N}_{2} \mathrm{O}$, and $\mathrm{N}_{2}$ ), but the $\mathrm{N}$ emissions decrease once reached the maximum. No clear trend between $\mathrm{S}$ sequestration and emissions $\left(\mathrm{H}_{2} \mathrm{~S}\right)$ has been found. Comparing the wetlands affected by agricultural inputs and those without, we found that the emission of $\mathrm{C}$ and $\mathrm{N}$ is greater in those with fertilization for the same amount of $\mathrm{C}$ and $\mathrm{N}$ sequestered; in contrast, the two values almost coincide for $\mathrm{S}$ sequestration.

The total long-term average of sequestered C, N, and S is $575 \mathrm{Tg} \mathrm{C}_{\text {year }}^{-1}, 20 \mathrm{Tg} \mathrm{N}_{\text {year }}^{-1}$, and $7.4 \mathrm{Tg} \mathrm{S} \mathrm{year}^{-1}$, respectively. In terms of sum per degree latitude (Figures $4 \mathrm{~b}, 4 \mathrm{e}$, and $4 \mathrm{~h}$ ), there are two peaks: the first across $60^{\circ} \mathrm{N}$ and the second in the tropical area. The total value for carbon sequestration is lower than the one found in Mitsch et al. (2013), however, that value is an estimation from 21 wetlands distributed globally.

\subsection{Controlling Variables}

We analyzed the dominant variables that affect each GHG emission and nutrient sequestration rate, and we investigated whether these effects are associated with the KG climatic class. Figures 5 and 6 report the Pearson correlation coefficient between pairs of variables sorted from the positive (red) to the negative (blue) correlation.

The SOM input in the system (label SOM input) has the highest correlation with all the three GHG emissions and the forcing variables. This correlation also helps to explain why the $\mathrm{N}_{2} \mathrm{O}$ emissions are high in northeast and southeast of the USA, despite $\mathrm{N}$ fertilization ranges between 0.1 and $5 \mathrm{~kg} \mathrm{~N} \mathrm{ha}^{-1}$. Analyzing the aggregated KG classes, the net recharge (label P-ETA) has a positive but weak correlation with GHG. 

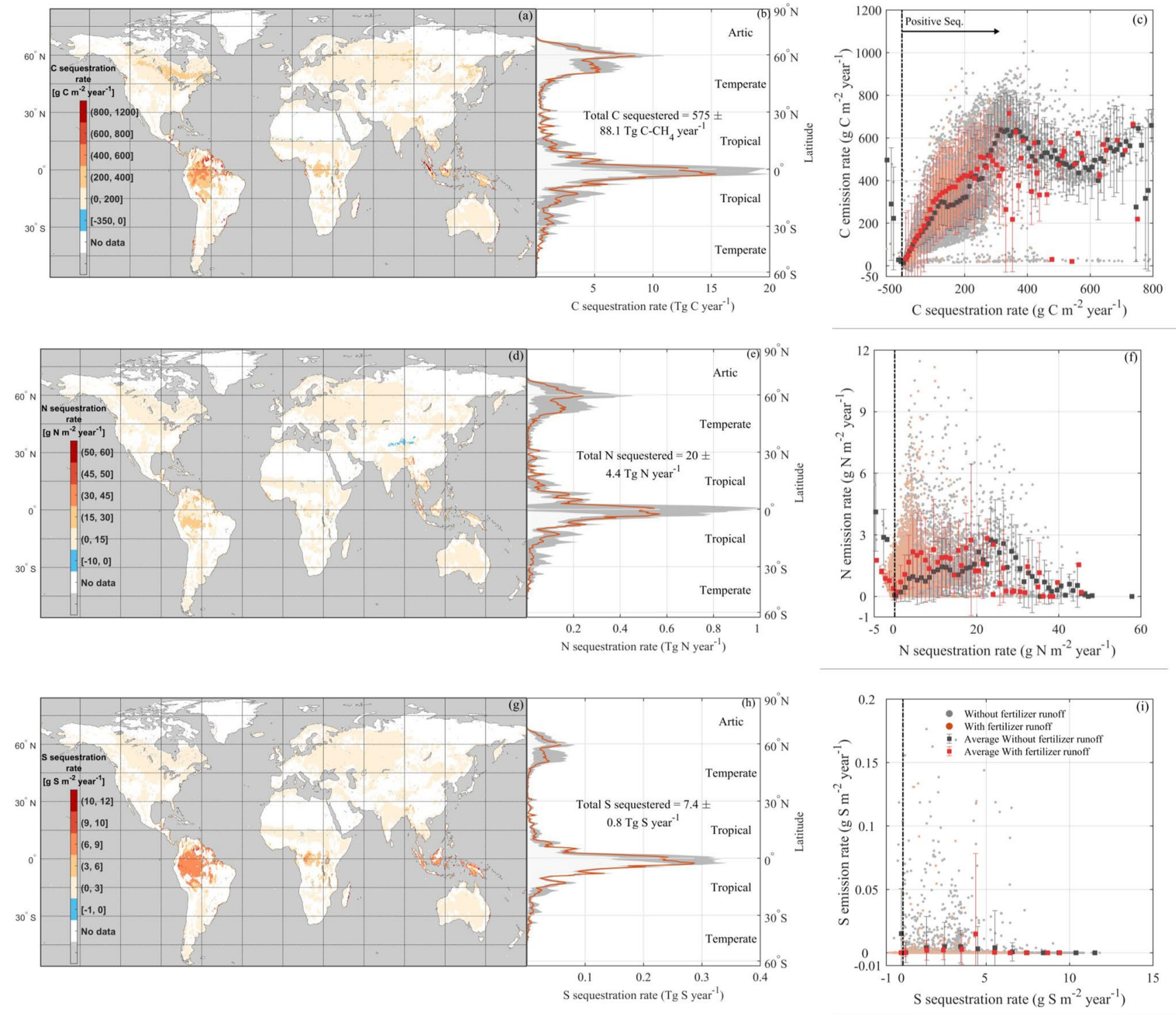

Figure 4. (a) Average annual carbon (C) sequestration, (b) average $\mathrm{C}$ total per $0.5^{\circ}$ latitude sequestration rate, and (c) average $\mathrm{C}$ sequestration against total $\mathrm{C}$ emissions $\left(\mathrm{CH}_{4}\right.$ and $\left.\mathrm{CO}_{2}\right)$; (d) average annual nitrogen $(\mathrm{N})$ sequestration, (e) average $\mathrm{N}$ total per $0.5^{\circ}$ latitude sequestration rate, and (f) average annual $\mathrm{N}$ sequestration against total $\mathrm{N}$ emissions ( $\mathrm{NO}, \mathrm{N}_{2} \mathrm{O}$, and $\mathrm{N}_{2}$ ); and (g) average annual sulfur (S) sequestration, (h) average $\mathrm{S}$ total per latitude $0.5^{\circ}$ sequestration rate, and (i) average annual S sequestration $\mathrm{S}$ emissions $\left(\mathrm{H}_{2} \mathrm{~S}\right)$. Each point represents a grid cell, while each square represents the bin average of a step of $10 \mathrm{~g} C$ $\mathrm{m}^{-2}$ year $^{-1}, 1 \mathrm{~g} \mathrm{~N} \mathrm{~m}^{-2}$ year $^{-1}$, and $\mathrm{g} \mathrm{S} \mathrm{m}{ }^{-2}$ year $^{-1}$.

However, a strong correlation was found in the continental regions (Dwa/Dwb/Dwc/Dwd/Dfa/Dfb classes), which tends to have a variable precipitation regime. N, P, and S fertilizations (labeled as N, P, and S Fert.) have weak correlations with each GHG emissions, either positive or negative depending on the target variable. $\mathrm{N}$ and $\mathrm{S}$ fertilizations have a weak and negative correlation with $\mathrm{CH}_{4}$, likely because the amended $\mathrm{N}$ and $\mathrm{S}$ increase the substrate competition and inhibition, except in the arid (Bsk and Bwh) and continental (Dfa) wetlands, where we found a positive correlation. In general, these are nutrient-poor environments, meaning that additional $\mathrm{N}$ input helps to sustain the microbial activity. $\mathrm{N}_{2} \mathrm{O}$ emission and $\mathrm{N}$ and $\mathrm{S}$ fertilization are generally positively correlated but are weakly negatively correlated in the temperate regions $(\mathrm{Cs} / \mathrm{Cwa} / \mathrm{Cwb} /$ $\mathrm{Cwc} / \mathrm{Cfa} / \mathrm{Cfb} / \mathrm{Cfc}$ ).

Wetland GHG emissions are significantly correlated with microbial diversity. We found that $B_{M G B}$ is positively correlated not only with $\mathrm{CH}_{4}$ and $\mathrm{CO}_{2}$ emissions, which are the direct products of the reaction $\mathrm{R} 6$ 
Table 1

Annual Average Nutrient Sequestration Rates for Different Climatic Classes (Value $\pm \sigma$ of g C/N/S $\mathrm{m}^{-2} \mathrm{Year}^{-1}$ )

\begin{tabular}{lccccccc}
\hline Variable & Tropical & Arid & Temperate & Continental & Polar & Global & Reference \\
\hline C seq & $273.6 \pm 169.0$ & $31.7 \pm 26.1$ & $132.4 \pm 112.0$ & $113.1 \pm 63.6$ & $26.9 \pm 24.2$ & $120.37 \pm 122.5$ & This work \\
C seq $^{\text {a }}$ & $55.8-168.5$ & $39-85.3$ & $55.2-120$ & - & $15.6-137.1$ & - & Villa and Bernal (2018) \\
C seq $^{\text {b }}$ & - & - & $12-1,180$ & - & $2.96-407$ & Cheng et al. (2020) \\
N seq & $11.4 \pm 7.8$ & $0.3 \pm 0.9$ & $4.0 \pm 6.1$ & $2.9 \pm 2.1$ & $0.5 \pm 0.9$ & $3.75 \pm 5.6$ & This work \\
S seq & $4.19 \pm 2.99$ & $0.04 \pm 0.15$ & $0.65 \pm 1.35$ & $0.37 \pm 0.45$ & $0.05 \pm 0.14$ & $0.98 \pm 2.05$ & This work \\
Total C seq $^{c}$ & 563 & - & 160 & - & 111 & Mitsch et al. (2013) \\
Total C seq $^{\mathrm{c}}$ & 368 & - & 152 & - & 55 & 575 & This work \\
\hline
\end{tabular}

${ }^{a}$ Upper and lower edges are the 25 th and 75 th quantiles. ${ }^{b}$ Minimum and maximum values of the range. ${ }^{c}$ Total carbon sequestration $\left(\mathrm{Tg} \mathrm{C}^{\mathrm{C}}\right.$ year ${ }^{-1}$ ).

(methanogenesis) and R7 (methane oxidation), but also with $\mathrm{N}_{2} \mathrm{O}$ emissions. The presence of $B_{M G B}$ guarantees anaerobic conditions necessary for denitrification. The same trade-off explains the high correlation between $B_{D E N}$ and $\mathrm{CH}_{4}$ and $\mathrm{CO}_{2}$ emissions.

Interestingly, we found that among the soil variables, the simulated soil organic carbon (label SOC) has the highest correlation with each GHG, while temperature did not have a significant effect, in particular on $\mathrm{CO}_{2}$ emissions (see also Section 3.5). Finally, $\mathrm{pH}$ has a negative correlation with all the target variables except

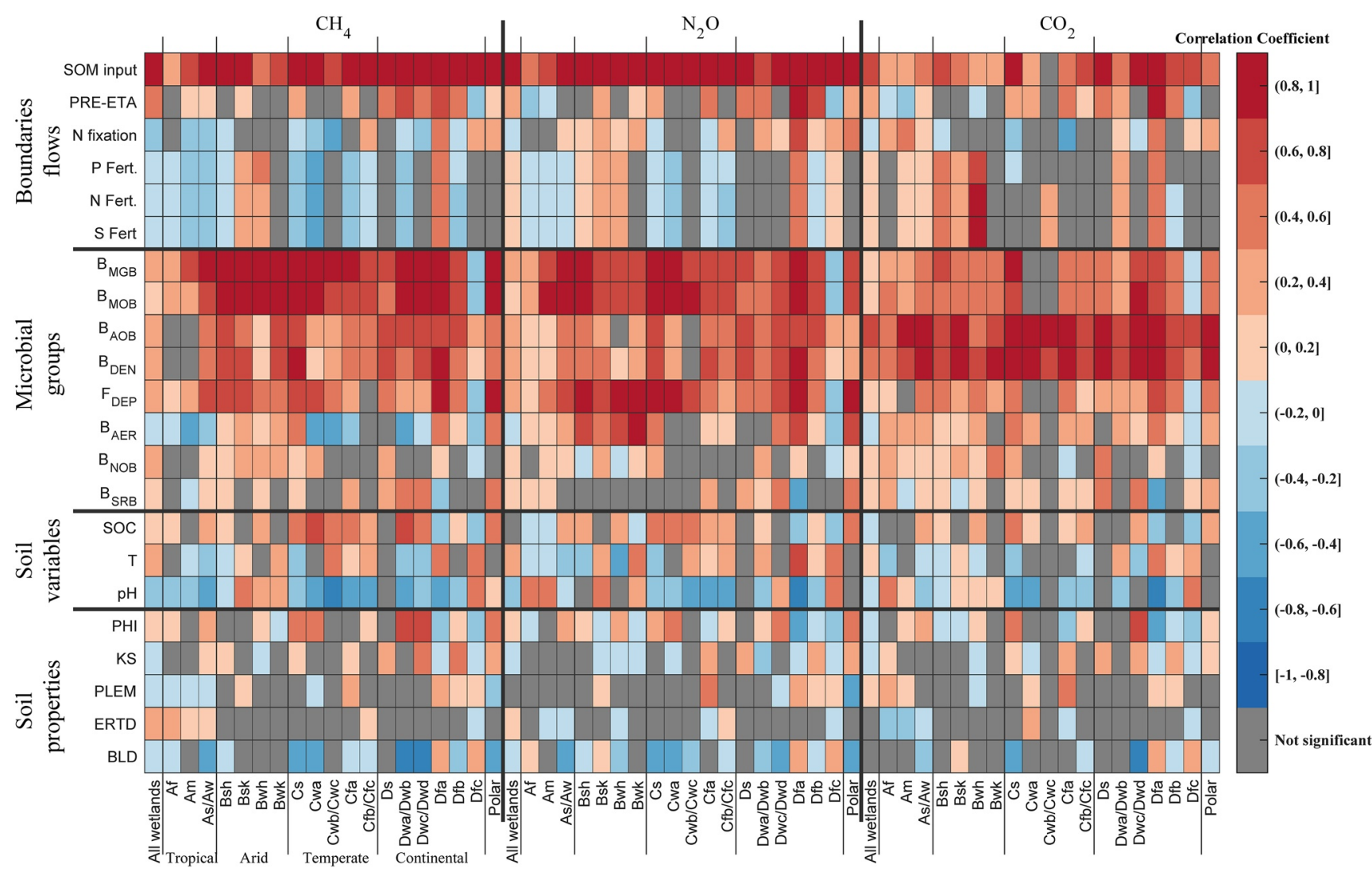

Figure 5. Pearson coefficient of forcing for carbon input (label SOM input), net recharge (label PRE-ETA), $\mathrm{N}_{2}$ fixation (N fixation), and P, N, and $\mathrm{S}$ fertilization (label P, N, S Fert.), microbial functional groups concentration, that is, $B_{M G B}, B_{M O B}, B_{A O B}, B_{D E N}, F_{D E P}, B_{A E R}, B_{S R B}$, and $B_{N O B}$, soil variables, that is, soil organic carbon

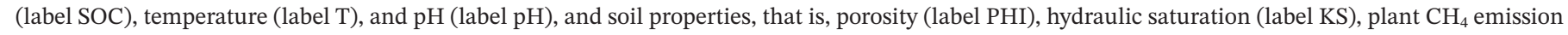
efficiency (label PLEM), root depth (label ERTD), and bulk density (label BLD), against long-term average annual $\mathrm{CH}_{4}, \mathrm{CO}_{2}$, and $\mathrm{N}_{2} \mathrm{O}$ emissions during 20002017. Results in each group are sorted from the highest positive (red) to the lowest negative (blue) correlation coefficient values. SOM, soil organic matter. 


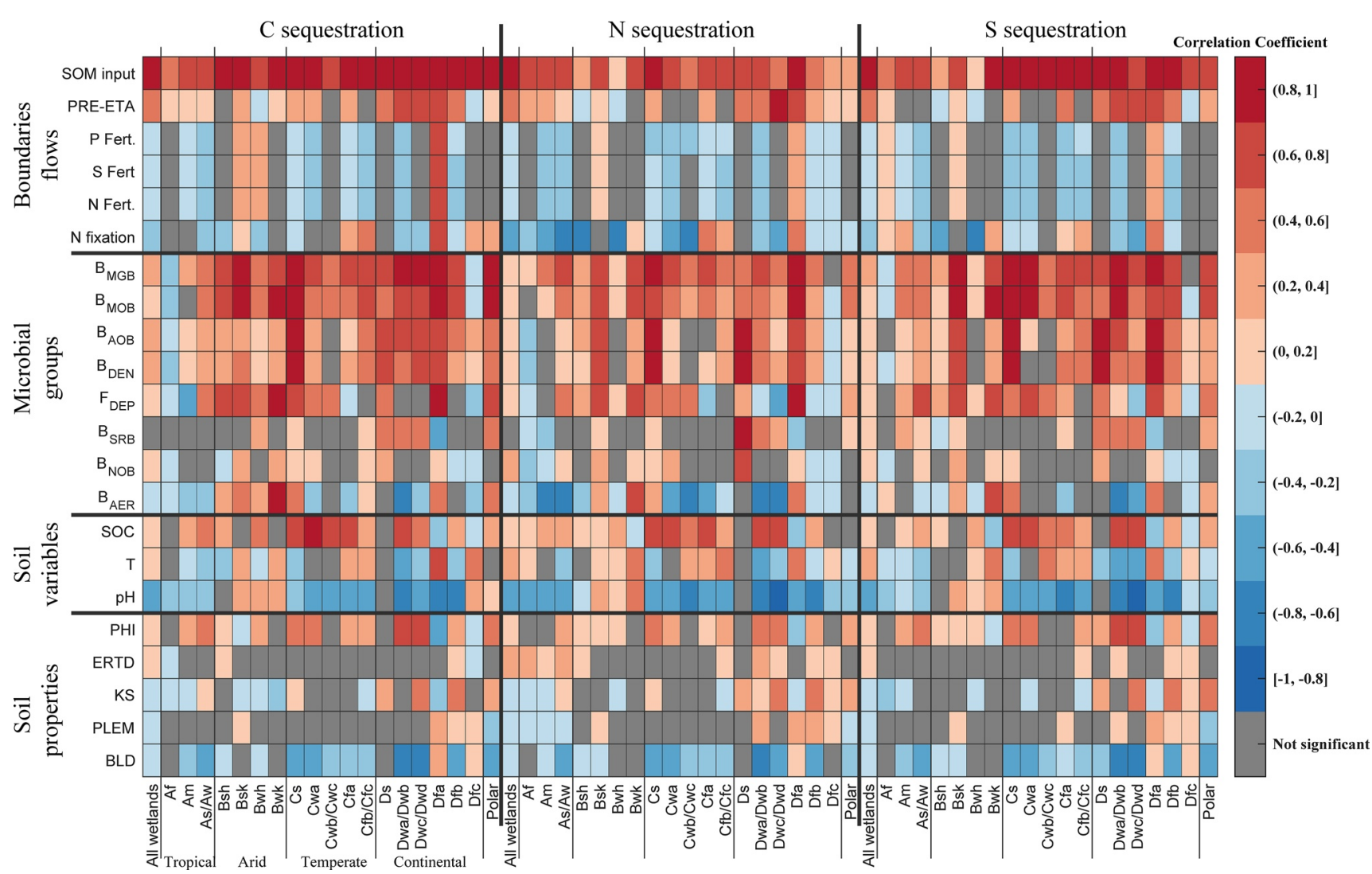

Figure 6. Pearson coefficient of forcing for carbon input (label SOM input), net recharge (label PRE-ETA), $\mathrm{N}_{2}$ fixation (N fixation), and P, N, and S fertilization (label P, N, S Fert.), microbial functional groups concentration, that is, $B_{M G B}, B_{M O B}, B_{A O B}, B_{D E N}, F_{D E P}, B_{A E R}, B_{S R B}$, and $B_{N O B}$, soil variables, that is, soil organic carbon (label SOC), temperature (label T), and $\mathrm{pH}$ (label pH), and soil properties, that is, porosity (label PHI), hydraulic saturation (label $\mathrm{KS}$ ), plant $\mathrm{CH}_{4}$ emission efficiency (label PLEM), root depth (label ERTD), and bulk density (label BLD), against long-term average annual carbon (C), nitrogen (N), and sulfur (S) sequestration rate. Results in each group are sorted from the highest positive (red) to the lowest negative (blue) correlation coefficient values. SOM, soil organic matter.

in the arid and tropical climates (Af/Am/As/Aw), where it positively affects $\mathrm{CH}_{4}, \mathrm{~N}_{2} \mathrm{O}$, and $\mathrm{CO}_{2}$. Of all the soil properties, none seems relevant to GHG emissions except the porosity (label PHI), which is positively correlated with $\mathrm{CH}_{4}$ in some temperate and continental regions (Cs/Cwa and Dwa/Dwb/Dwc/Dwd), and bulk density (label BDL), which is negatively correlated with $\mathrm{CH}_{4}, \mathrm{CO}_{2}$, and $\mathrm{N}_{2} \mathrm{O}$ in some continental regions (Dwa/Dwb/Dwc/Dwd).

The carbon input (label SOM input) has the highest and most uniform correlation among all the forcing conditions against each nutrient sequestration. By contrast, $\mathrm{N}$, P, and $\mathrm{S}$ fertilizations (labeled as N, P, and S Fert.) have a weak negative correlation because the fertilizer increases the input of rapidly degradable substrates. However, in the arid (Bsk and Bwh) and continental (Dfa) wetlands, we found a positive correlation with fertilizer input. As mentioned above, additional nutrient inputs to these soils helps to sustain microbial activity, but because of the extreme temperature and precipitation regimes, only a part of the fertilizer nutrients are sequestered in the soil matrix. Increases in microbial activity decrease nutrient sequestration. In particular, heterotrophic respiration is 10 times faster than the anaerobic one. In fact, we found that $B_{M G B}$ is highly positively correlated with sequestration of all nutrients, while $B_{A E R}$ is negatively correlated in most of the KG classes.

Among the soil variables, the simulated soil organic carbon (label SOC) is the most highly correlated with sequestration of $\mathrm{C}, \mathrm{N}$, and $\mathrm{S}$, while $\mathrm{pH}$ is strongly negatively correlated, except in arid regions (Bsk/Bwh/ Bwk). As per GHG emissions, the porosity (label PHI) is positively correlated with each KG class, and the bulk density (label BDL) is negatively correlated. 

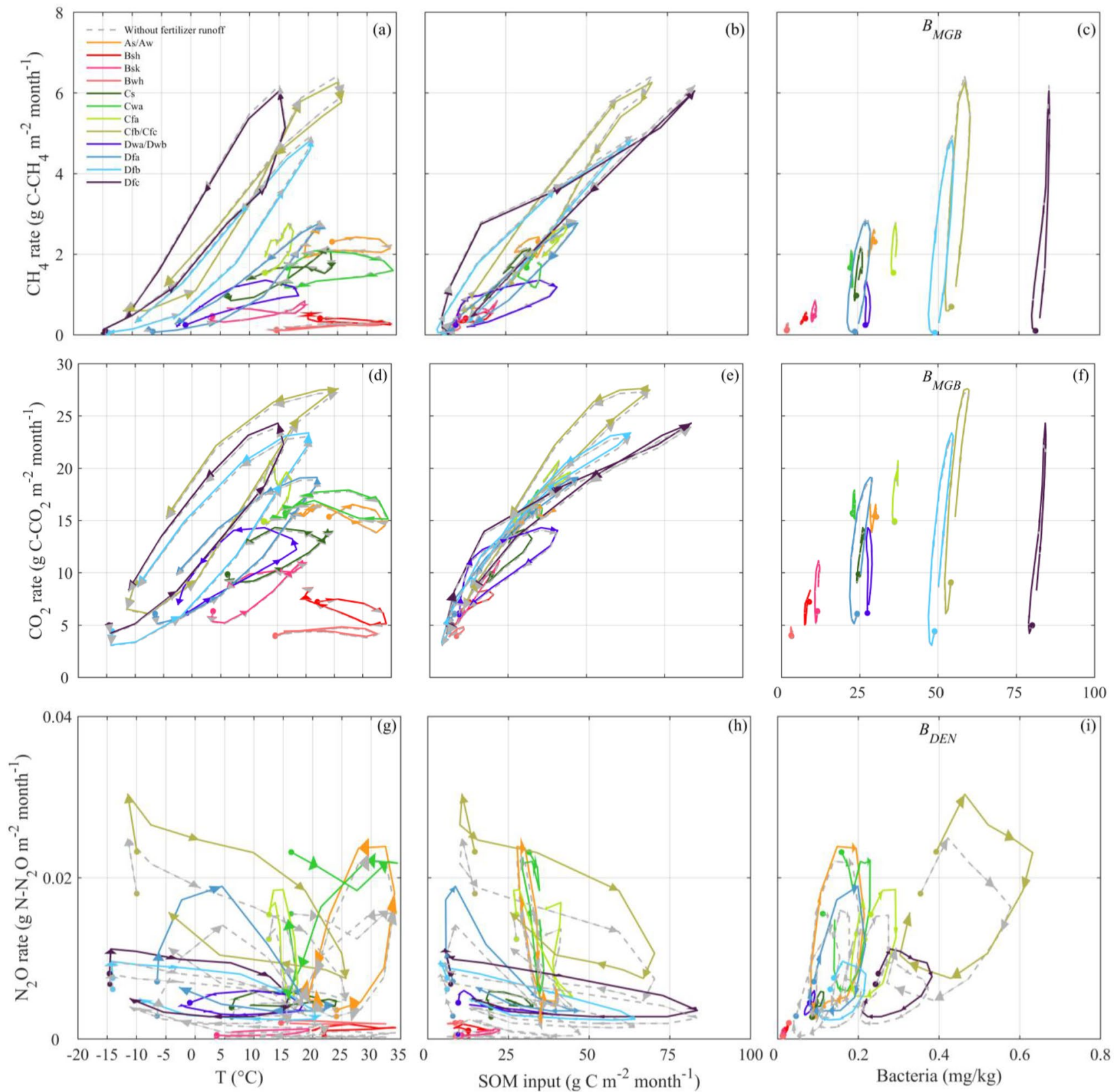

Figure 7. Dynamic analysis: $\mathrm{CH}_{4}$ with changing temperature (a), $\mathrm{SOM}$ input (b), and $B_{M G B}$ concentration (c) during 1 year; $\mathrm{CO}_{2}$ with changing temperature (d), SOM input (e), and $B_{M G B}$ concentration (f) during 1 year; $\mathrm{N}_{2} \mathrm{O}$ with changing temperature (g), SOM input (h), and $B_{D E N}$ concentration (i) during 1 year; January is the initial point, represented with a dot, then the arrow shows the direction. Data refer only the grid cells affected by agricultural runoff. Gray dashed line represents each KG class without fertilization inputs. SOM, soil organic matter; KG, Köppen-Geiger.

\subsection{Dynamic Analysis}

We examined if a specific subseasonal relationship exists between GHG emissions and temperature, SOM input, $B_{M G B}$, and $B_{D E N}$, and whether fertilizer inputs affect this relationship. The KG climate classification groups wetlands within the same climate and the same or similar vegetation cover (Rohli et al., 2015). The starting point (January) is represented in Figure 7 with a dot while the arrow shows the time direction. Figure 7 reports only the KG classes (and therefore only the grid cells) affected by fertilization inputs, while Figure S11, shows the results for all KG classes. 
Fertilization inputs slightly decrease $\mathrm{CH}_{4}$ emissions (Figures 7a-7c) due to electron competition except in arid regions (Bsh, Bsk, and Bwh), where the emissions remain almost constant. In contrast, $\mathrm{CO}_{2}$ emissions increase slightly (Figures 7d-7f) because of a decrease in $\mathrm{CH}_{4}$ production and oxidation, and a significant increase in $\mathrm{N}_{2} \mathrm{O}$ production (Figures $7 \mathrm{~g}-7 \mathrm{i}$ ). We found hysteresis in the relationship between $\mathrm{CH}_{4}$ and $\mathrm{CO}_{2}$ emissions and temperature, with higher emissions during autumn than in spring at the same temperature (Chang et al., 2020), while SOM input and $B_{M G B}$ do not.

Dry climates (Bsh, Bsk, and Bwh) have the lowest $\mathrm{CH}_{4}$ emissions and do not show a wide hysteresis against temperature (Figure 7a). These areas have extreme temperatures that affect the vegetation (the major biome is desert, Rohli et al., 2015), with very low SOM input (Figure 7b). The tropical area is divided into two groups: rain forest (Af and Am in Figure S11) has high $\mathrm{CH}_{4}$ emissions, $\mathrm{SOM}$ input, and $B_{M G B}$ concentrations and is not affected by agricultural runoff; and the savanna (As/Aw), characterized mainly by grasslands (Rohli et al., 2015) with low SOM input, emissions, and $B_{M G B}$ concentrations. Continental and temperate regions show the most significant change in $\mathrm{CH}_{4}$ emissions as a function of temperature (Figure 7a). Despite the highest emissions in Dfc (subarctic), Dfb (warm summer continental), and $\mathrm{Cfb} / \mathrm{Cfc}$ (humid subtropical climate and oceanic climate), the effect of fertilizer is minor. Dfc and Dfb are characterized by grassland, peatland, and temperate forest (Rohli et al., 2015); hence, the annual SOM input is very high (Figure 7b), while $\mathrm{Cfb} / \mathrm{Cfc}$ is characterized by tundra, grassland, and temperate forest, with high SOM input during summertime. Surprisingly, the $B_{M G B}$ concentration is quite stable over the year in each KG climatic group, with no significant changes, even accounting for fertilization (Figure 7c).

$\mathrm{CO}_{2}$ emissions show dynamics similar to $\mathrm{CH}_{4}$, highlighting again the strong correlation between these two gases (Figures 7d-7f).

Figures $7 \mathrm{~g}-7 \mathrm{i}$ show very different dynamics for $\mathrm{N}_{2} \mathrm{O}$ emissions, with no hysteresis against temperature and a much wider cycle due to fertilization. Moreover, higher average emissions occur around April in $\mathrm{Cfb} / \mathrm{Cfc}$, $\mathrm{Cfa}$, Dfb, Dfc, Dfa, and Cwb/Cwc climatic regions (Figure $7 \mathrm{~g}$ ). Emissions in tropical areas are lower than in other areas because of fewer anthropogenic pressures, including agricultural fertilization (Figures 7g-7i and S11g-S11i). In addition, tropical areas consist of rainforest (Rohli et al., 2015), therefore the C:N litter aboveground is very high $\left(\mathrm{C}: \mathrm{N}_{N P P_{A B}}=64.30\right)$, releasing less $\mathrm{N}$ to the soil. Additional moderate inputs of $\mathrm{N}$ fertilizer have little effect on emissions. $B_{D E N}$ dynamics are very similar to $\mathrm{CO}_{2}$ or $\mathrm{CH}_{4}$ emissions and $B_{M G B}$, with little change over the year (Figure 7i); however, here, fertilizers have a significant effect on biomass, in particular in the $\mathrm{Cfb} / \mathrm{Cfc}$ and Dfa classes.

\section{Discussion}

Current global estimates of wetland $\mathrm{CH}_{4}$ emissions range between 95 and $213 \mathrm{Tg} \mathrm{C}-\mathrm{CH} 4$ year ${ }^{-1}$ (Kirschke et al., 2013; L. Liu et al., 2020; Melton et al., 2013; Poulter et al., 2017; Saunois et al., 2020; Tian et al., 2015; Zhu et al., 2015) across different historical periods, different estimation approaches, different climatic forcing, and wetland area fractions. Here, we estimated an average $\mathrm{CH}_{4}$ global emission of $135 \mathrm{Tg} \mathrm{C}-\mathrm{CH}_{4}$ year $^{-1}$ between 2000 and 2017. On average, our estimates are slightly greater than other bottom-up estimates in Saunois et al. (2020) (Figure S10b) but still in the range of top-down estimated emissions. Most of the current models linked $\mathrm{CH}_{4}$ production to NPP, temperature, $\mathrm{pH}$, and redox conditions using multiplication factors, but without accounting for microbial growth and carbon sequestration dynamics, the latter being very important in C-rich northern peatlands. Rising temperature and permafrost thawing make part of prestocked $\mathrm{C}$ in these areas available to microorganisms, thus increasing GHG emissions significantly (Baldwin et al., 2014; Davidson \& Janssens, 2006; Kuhn et al., 2018). The tropical area is also the primary contributor to intra-annual variations given its favorable temperature and persistently large wetland fractional area. The northern latitudes contribute most of the high intra-annual variability (Figure 3).

Agronutrient inorganic fertilization had minor effects on wetland $\mathrm{CH}_{4}$ and $\mathrm{CO}_{2}$ emissions but significantly affected the $\mathrm{N}_{2} \mathrm{O}$ emissions (Barnard et al., 2005; Kroeze \& Seitzinger, 1998). Neglecting runoff of $\mathrm{N}$ from fertilization would underestimate the available concentration of $\mathrm{NH}_{4}^{+}$and $\mathrm{NO}_{3}^{-}$in wetland soils (Morse et al., 2012), resulting in $13 \%$ reduction in $\mathrm{N}_{2} \mathrm{O}$ emissions in the Northern Hemisphere. The overall emission of $\mathrm{N}_{2} \mathrm{O}$ from wetlands is not particularly high compared to agriculture's contribution. However, $\mathrm{N}_{2} \mathrm{O}$ 
is almost 300 times more powerful as a GHG than $\mathrm{CO}_{2}$, which could represent a potential problem, both in terms of global warming and biodiversity conservation. Nutrient-rich inputs to wetlands also increase plant productivity and may change the dominant plant composition (Egertson et al., 2004; Hagerthey et al., 2008; Johnson \& Rejmánková, 2005), thus directly affecting nutrient decomposition, retention, and turnover rates (Verhoeven et al., 2006). Increased nutrient inputs, together with an increase in temperature, may increase $\mathrm{N}_{2} \mathrm{O}$ emissions synergistically after considering the positive correlation between the two variables (Figure 5). The relationship between emissions and either temperature or SOM input shows a high degree of complexity (Figure 7) as it strongly depends on the type of major biomes present. A deeper understanding of these dynamics in each climatic region may give a better description of SOM input in terms of quality (C:N and C:S litter ratio) and quantity (amount of litter entering the soil) and could be used to improve descriptions of biogeochemical cycles in wetlands. Moreover, $\mathrm{N}$ fertilization was positively correlated with $\mathrm{CH}_{4}$ emissions in arid climates, where additional $\mathrm{N}$ helped to sustain microbial activity in a nutrient-poor environment.

The addition of fertilizers interferes not only with the biogeochemical cycles of a wetland but also with the ecological system. Reis et al. (2017) estimated the impact of human pressure on inland wetlands and found that tropical areas, although generally pristine, have the highest "human influential factor" due to forest conversion into agricultural land and for population expansion. Both contributions may result in a high nutrient load reaching the wetland, thus altering the emissions, and the ecological equilibrium, that is, increasing eutrophication and threatening the local fauna. The actual impact of agriculture is more complex, and it involves consideration of essential ecosystem services (McBratney et al., 2014). A better framework that combines complex biogeochemical and ecosystem service assessment is essential to set up a more effective conservation plan.

Our results demonstrated the importance of accounting for coupled protection, dissolved, and gaseous phases. We found that the tropical and temperate climates showed the highest rates of nutrient sequestration, followed by continental, polar, and arid climates, in agreement with previous literature (Table 1). Our modeled global average $\mathrm{C}$ sequestration rate is $120.4 \mathrm{~g} \mathrm{C} \mathrm{m}^{-2}$ year $^{-1}$ regardless of the type of wetland or climatic class and is lower than in Cheng et al. (2020), who reported $185.2 \mathrm{~g} \mathrm{C} \mathrm{m}^{-2}$ year $^{-1}$. We also found that high $\mathrm{C}$ and $\mathrm{N}$ sequestration rates (e.g., $350 \mathrm{~g} \mathrm{C} \mathrm{m}^{-2}$ year $^{-1}$ and $22 \mathrm{~g} \mathrm{~N} \mathrm{~m}^{-2}$ year ${ }^{-1}$ ) coincide with high gas emission rates, similar to field experiments in Nahlik and Mitsch (2010) and Bernal and Mitsch (2013). This result indicates that high SOM input rates positively affect emissions, supplying substrate to soil microorganisms, and concurrently leading to a high potential sequestration rate. It also highlights the strong link between factors that affect microbial dynamics and soil sequestration and the need for these processes to be described together (Villa \& Bernal, 2018). BRTSim-BAMS4 can allocate the carbon input in different pools, that is, slow and fast biodegradable constituents. Having highly mobile species and highly protected species that dynamically change according to local conditions provides a better nutrient budget balance at different time scales.

We found that fertilization inputs do not promote $\mathrm{C}, \mathrm{N}$, and $\mathrm{S}$ sequestration, and the two variables are weakly negatively correlated in contrast to results from Cheng et al. (2020). However, additional $\mathrm{N}$ inputs help sustain plant growth particularly in nutrient-poor environments such as in arid areas, thus resulting in greater emissions and also sequestration (Hobbie, 2005). Another important factor controlling the emission is the temperature, which indirectly affects the plant yield, hence the SOM input, and the biological reaction rates, even if only the latter feature was included in our model formulation.

As with all models, uncertainties exist in our model projections. BRTSim-BAMS4 includes a wide range of complex biogeochemical reactions and feedback responses from the environment. Here, we did not investigate the errors in parameters that may affect the level of uncertainty of this study, although a sensitivity analysis was developed in previous works with the parent reaction network (Ceriotti et al., 2020; Pasut et al., 2020), highlighting the main biogeochemical processes that controls GHG emissions and C and $\mathrm{N}$ stocks in different ecosystems and hydroclimatic conditions. Whether the $13 \%$ decrease in $\mathrm{N}_{2} \mathrm{O}$ emissions is within the order of magnitude of the model error is uncertain. More long-term observations of $\mathrm{N}_{2} \mathrm{O}$ emission from flux towers in wetlands are required, but these are still a great challenge. In addition, both the reaction networks and simulation setup may be improved. For instance, both wetland and cropland areas have likely changed in these last 18 years, while we only account for changes in wetland area. A better 
description should also include cropland expansion and therefore variable quality and quantity of runoff. Additionally, the biochemical kinetic parameters in the model are all spatially homogeneous, except for a few specific parameters that are vegetation dependent (e.g., C:N ratio of $\mathrm{NPP}_{A G}, \mathrm{~N}_{2}$ fixation, root depth, and $\mathrm{CH}_{4}$ plant emission efficiency). Neglecting the spatial distribution of these parameters results in a simplified description of microbial adaptation, which may introduce uncertainties in tropical areas, where $\mathrm{pH}$ is, on average, very low (Menne et al., 2012) and the temperature is mostly continuously high, and in northern latitudes, where temperatures are very low (Meng et al., 2012; Zhu et al., 2015). The effect of pH on each biologically mediated reaction was taken into account using a Michaelis-Menten term describing the microbial growth as neutrophil (Paul, 2014), hence with optima between pH 5 and 8. However, it has been found that the reduction of $\mathrm{N}_{2} \mathrm{O}$ to $\mathrm{N}_{2}$ is slowed down, sometimes even prevented, in acid soils, thus resulting in high $\mathrm{N}_{2} \mathrm{O}$ emissions (B. Liu et al., 2014). This may significantly affect the estimated emissions in peat soil, where the average $\mathrm{pH}$ is lower than 6. Despite the complexity of the reaction network described here, some biogeochemical processed are still missing in BAMS4. For instance, we do not account for iron, manganese, and copper cycles, and their relationship with sulfur precipitation, $\mathrm{C}$ cycle mineralization rate (Luke et al., 2015), and toxicity to plants and bacteria, because these processes have not been fully understood yet. For the simulation setup, we used a dynamic wetland area to postprocess the data, thus potentially introducing uncertainties in our estimates (Petrescu et al., 2010). Neglecting a proper description of the expansion and contraction of the wetland area may only partially describe the $\mathrm{O}_{2}$ diffusion in soil, hence the redox potential control on microbial processes. In addition, the effect of catchment drainage can be improved by accounting for point sources such as urban drainage, wastewater, and livestock discharges, which have recently been addressed as major sources of $\mathrm{N}$ input in watersheds (Bao et al., 2019). Finally, the runoff model does not explicitly account for river and stream flow. It has been found that $\mathrm{N}_{2} \mathrm{O}$ emission rates strongly depend on the flow rate, river size, and the order of the stream of the river (Marzadri et al., 2017; Turner et al., 2015). Hence, similar pattern may occur to wetlands: depending on their position in the catchment, they can be affected differently by dilution and previous degradation, affecting the nutrients turnover.

\section{Conclusions}

We found that fertilizer inputs mainly affect $\mathrm{N}_{2} \mathrm{O}$ emissions in the Northern Hemisphere, and neglecting them may underestimate by $13 \%$ the $\mathrm{N}_{2} \mathrm{O}$ emissions. SOM input, SOC, temperature, and methanogenic bacteria are the major variables affecting GHG emissions and $\mathrm{C}, \mathrm{N}$, and $\mathrm{S}$ sequestration. We also found hysteresis in the relationship of temperature with $\mathrm{CH}_{4}$ and $\mathrm{CO}_{2}$ emissions over a year, but not with $\mathrm{N}_{2} \mathrm{O}$. Fertilization does not modify this relationship; however, $\mathrm{CH}_{4}$ emissions slightly decrease and $\mathrm{CO}_{2}$ emissions slightly increase with fertilization. Nutrient sequestration is one of the most important features of wetlands, and we found that for an equal $\mathrm{C}$ and $\mathrm{N}$ stock, wetlands affected by agriculture have higher GHG emissions. Our results show that coupling SOM with $\mathrm{N}$ and S cycles may support a more comprehensive biogeochemical model assessment of a wetland, both in terms of emissions and sequestration, including ecological feedbacks regulating microbial responses. Our results point out the need to focus future research on linking nutrient cycles and their complex dynamics in different phases to improve past, present, and future assessment of global nutrient budgets.

\section{Data Availability Statement}

We distribute the model output of $\mathrm{CH}_{4}, \mathrm{CO}_{2}$, and $\mathrm{N}_{2} \mathrm{O}$ emissions, soil temperature, soil moisture, long-term average soil $\mathrm{pH}$, carbon input, long-term average annual carbon, long-term average soil carbon, nitrogen, and sulfur sequestration rate. We include also $\mathrm{CH}_{4}$ plant emission efficiency for aerenchyma transport, $\mathrm{C}: \mathrm{N}$ and C:S ratio of litter in grassland, forest, and shrubland, $\mathrm{N}_{2}$ fixation rate in grassland, forest, shrubland, and wetland, and the average root density for forest, grassland, shrublands, and wetland. All the data are at $0.5^{\circ} \times 0.5^{\circ}$ resolution, released in . NC format and available at https://figshare.com/s/e50db94ddffbaa0f8304. DOI: 10.6084/m9.figshare.12904385. 
Acknowledgments

This work was supported by the SREI2020 EnviroSphere research program and the SREI Voucher of the University of Sydney. The authors acknowledge the Sydney Informatics Hub and the University of Sydney's high performance computing cluster Artemis for providing the high performance computing resources that have contributed to the results reported within this work. The authors acknowledge the use of the National Computational Infrastructure (NCI) which is supported by the Australian Government, and accessed through the Sydney Informatics Hub HPC Allocation Scheme, which is supported by the Deputy Vice-Chancellor (Research), University of Sydney and the ARC LIEF, 2019: Smith, Muller, Thornber, et al., Sustaining and strengthening merit-based access to National Computational Infrastructure (LE190100021). William J. Riley was supported by U.S. Department of Energy, Office of Science, Biological and Environmental Research, Regional and Global Climatic Modeling Program through the RUBISCO Scientific Focus Area under contract DE-AC0205CH11231 to Lawrence Berkeley National Laboratory.

\section{References}

Abbott, B. W., \& Jones, J. B. (2015). Permafrost collapse alters soil carbon stocks, respiration, $\mathrm{CH}_{4}$, and $\mathrm{N}_{2} \mathrm{O}$ in upland tundra. Global Change Biology, 21(12), 4570-4587.

Arora, V. K., Melton, J. R., \& Plummer, D. (2018). An assessment of natural methane fluxes simulated by the CLASS-CTEM model. Biogeosciences, 15(15), 4683-4709.

Baldwin, A. H., Jensen, K., \& Schönfeldt, M. (2014). Warming increases plant biomass and reduces diversity across continents, latitudes, and species migration scenarios in experimental wetland communities. Global Change Biology, 20(3), 835-850.

Bao, W., Yang, Y., Fu, T., \& Xie, G. H. (2019). Estimation of livestock excrement and its biogas production potential in china. Journal of Cleaner Production, 229, 1158-1166.

Barnard, R., Leadley, P. W., \& Hungate, B. A. (2005). Global change, nitrification, and denitrification: A review. Global Biogeochemical Cycles, 19, GB1007. https://doi.org/10.1029/2004GB002282

Beerling, D. J., Fox, A., Stevenson, D. S., \& Valdes, P. J. (2011). Enhanced chemistry-climate feedbacks in past greenhouse worlds. Proceedings of the National Academy of Sciences, 108(24), 9770-9775.

Bernal, B., \& Mitsch, W. J. (2013). Carbon sequestration in two created riverine wetlands in the midwestern United States. Journal of Environmental Quality, 42(4), 1236-1244.

Bloom, A. A., Bowman, K. W., Lee, M., Turner, A. J., Schroeder, R., Worden, J. R., \& Jacob, D. J. (2017). A global wetland methane emissions and uncertainty dataset for atmospheric chemical transport models (WetCHARTs version 1.0). Geoscientific Model Development, 10(6), 2141-2156.

Bonnett, S. A. F., Blackwell, M. S. A., Leah, R., Cook, V., O'Connor, M., \& Maltby, E. (2013). Temperature response of denitrification rate and greenhouse gas production in agricultural river marginal wetland soils. Geobiology, 11(3), 252-267.

Bréchet, L., Le Dantec, V., Ponton, S., Goret, J.-Y., Sayer, E., Bonal, D., et al. (2017). Short- and long-term influence of litter quality and quantity on simulated heterotrophic soil respiration in a lowland tropical forest. Ecosystems, 20(6), 1190-1204.

Bronson, K. F., Neue, H.-U., Abao, E. B., \& Singh, U. (1997). Automated chamber measurements of methane and nitrous oxide flux in a flooded rice soil: I. Residue, nitrogen, and water management. Soil Science Society of America Journal, 61, 981-987.

Brooks, R. H., \& Corey, A. T. (1964). Hydraulic properties of porous media. In Hydrology papers (No. 3). Colorado State University.

Brown, J., Ferrians, O., Jr., Heginbottom, J., \& Melnikov, E. (2001). Circum-arctic map of permafrost and ground-ice conditions (National Snow and Ice Data Center/World Data Center for Glaciology, Boulder, CO). Digital Media.

Burgin, A. J., \& Groffman, P. M. (2012). Soil $\mathrm{O}_{2}$ controls denitrification rates and $\mathrm{N}_{2} \mathrm{O}$ yield in a riparian wetland. Journal of Geophysical Research, 117, G01010. https://doi.org/10.1029/2011JG001799

Canadell, J., Jackson, R. B., Ehleringer, J. B., Mooney, H. A., Sala, O. E., \& Schulze, E.-D. (1996). Maximum rooting depth of vegetation types at the global scale. Oecologia, 108(4), 583-595. https://doi.org/10.1007/bf00329030

Ceriotti, G., Tang, F. H., \& Maggi, F. (2020). Similarities and differences in the sensitivity of soil organic matter (SOM) dynamics to biogeochemical parameters for different vegetation inputs and climates. Stochastic Environmental Research and Risk Assessment, 34, 2229-2244.

Chang, K.-Y., Riley, W. J., Brodie, E. L., McCalley, C. K., Crill, P. M., \& Grant, R. F. (2019). Methane production pathway regulated proximally by substrate availability and distally by temperature in a high-latitude mire complex. Journal of Geophysical Research: Biogeosciences, 124, 3057-3074. https://doi.org/10.1029/2019JG005355

Chang, K.-Y., Riley, W. J., Crill, P. M., Grant, R. F., \& Saleska, S. R. (2020). Hysteretic temperature sensitivity of wetland $\mathrm{CH}_{4}$ fluxes explained by substrate availability and microbial activity. Biogeosciences Discussions, 17, 5849-5860.

Cheng, C., Li, M., Xue, Z., Zhang, Z., Lyu, X., Jiang, M., \& Zhang, H. (2020). Impacts of climate and nutrients on carbon sequestration rate by wetlands: A meta-analysis. Chinese Geographical Science, 30(3), 483-492. https://doi.org/10.1007/s11769-020-1122-3

Cover, M. L., \& Change, L.-C. (1999). Modis Land Cover Product Algorithm Theoretical Basis Document (Atbd) Version 5.0; MODIS documentation (vol. 23, pp. 42-47). Maryland, USA: MODIS documentation; University of Maryland.

Dai, Y., Shangguan, W., Duan, Q., Liu, B., Fu, S., \& Niu, G. (2013). Development of a china dataset of soil hydraulic parameters using pedotransfer functions for land surface modeling. Journal of Hydrometeorology, 14(3), 869-887. https://doi.org/10.1175/jhm-d-12-0149.1

Davidson, E. A., \& Janssens, I. A. (2006). Temperature sensitivity of soil carbon decomposition and feedbacks to climate change. Nature, 440(7081), 165-173. https://doi.org/10.1038/nature04514

Dise, N. B., \& Verry, E. S. (2001). Suppression of peatland methane emission by cumulative sulfate deposition in simulated acid rain. Biogeochemistry, 53(2), 143-160. https://doi.org/10.1023/a:1010774610050

Egertson, C. J., Kopaska, J. A., \& Downing, J. A. (2004). A century of change in macrophyte abundance and composition in response to agricultural eutrophication. Hydrobiologia, 524(1), 145-156. https://doi.org/10.1023/b:hydr.0000036129.40386.ce

Friedl, M., \& Sulla-Menashe, D. (2015). MCD12Q1: MODIS/Terra + Aqua land cover type yearly L3 global 500m SIN grid v006. https://doi. org/10.5067/MODIS/MCD12Q1.006

Gauci, V., Matthews, E., Dise, N., Walter, B., Koch, D., Granberg, G., \& Vile, M. (2004). Sulfur pollution suppression of the wetland methane source in the 20th and 21st centuries. Proceedings of the National Academy of Sciences, 101(34), 12583-12587. https://doi.org/10.1073/ pnas.0404412101

Grant, R. F., Mekonnen, Z. A., \& Riley, W. J. (2019). Modeling climate change impacts on an arctic polygonal tundra: 1. Rates of permafrost thaw depend on changes in vegetation and drainage. Journal of Geophysical Research: Biogeosciences, 124, 1308-1322. https://doi. org/10.1029/2018JG004644

Grant, R. F., Mekonnen, Z. A., Riley, W. J., Arora, B., \& Torn, M. S. (2019). Modeling climate change impacts on an Arctic Polygonal Tundra: 2. Changes in $\mathrm{CO}_{2}$ and $\mathrm{CH}_{4}$ exchange depend on rates of permafrost thaw as affected by changes in vegetation and drainage. Journal of Geophysical Research: Biogeosciences, 124, 1323-1341. https://doi.org/10.1029/2018JG004645

Hagerthey, S. E., Newman, S., Rutchey, K., Smith, E. P., \& Godin, J. (2008). Multiple regime shifts in a subtropical peatland: Community-specific thresholds to eutrophication. Ecological Monographs, 78(4), 547-565. https://doi.org/10.1890/07-0538.1

Hättenschwiler, S., \& Jørgensen, H. B. (2010). Carbon quality rather than stoichiometry controls litter decomposition in a tropical rain forest. Journal of Ecology, 98(4), 754-763. https://doi.org/10.1111/j.1365-2745.2010.01671.x

Hayman, G. D., O'Connor, F. M., Dalvi, M., Clark, D. B., Gedney, N., Huntingford, C., et al. (2014). Comparison of the HadGEM2 climatechemistry model against in situ and SCIAMACHY atmospheric methane data. Atmospheric Chemistry and Physics, 14(23), 13257-13280. https://doi.org/10.5194/acp-14-13257-2014

Hengl, T., de Jesus, J. M., Heuvelink, G. B., Gonzalez, M. R., Kilibarda, M., Blagotić, A., et al. (2017). SoilGrids250m: Global gridded soil information based on machine learning. PLoS One, 12(2), e0169748. https://doi.org/10.1371/journal.pone.0169748 
Hobbie, S. E. (2005). Contrasting effects of substrate and fertilizer nitrogen on the early stages of litter decomposition. Ecosystems, 8(6), 644-656. https://doi.org/10.1007/s10021-003-0110-7

Hong, Y., \& Adler, R. F. (2008). Estimation of global SCS curve numbers using satellite remote sensing and geospatial data. International Journal of Remote Sensing, 29(2), 471-477. https://doi.org/10.1080/01431160701264292

Johnson, S., \& Rejmánková, E. (2005). Impacts of land use on nutrient distribution and vegetation composition of freshwater wetlands in northern Belize. Wetlands, 25(1), 89-100. https://doi.org/10.1672/0277-5212(2005)025[0089:ioluon]2.0.co;2

Kaushal, S. S., Groffman, P. M., Band, L. E., Elliott, E. M., Shields, C. A., \& Kendall, C. (2011). Tracking nonpoint source nitrogen pollution in human-impacted watersheds. Environmental Science \& Technology, 45(19), 8225-8232. https://doi.org/10.1021/es200779e

Kaushal, S. S., Mayer, P. M., Vidon, P. G., Smith, R. M., Pennino, M. J., Newcomer, T. A., et al. (2014). Land use and climate variability amplify carbon, nutrient, and contaminant pulses: A review with management implications. Journal of the American Water Resources Association, 50(3), 585-614. https://doi.org/10.1111/jawr.12204

Kaushal, S. S., Pace, M. L., Groffman, P. M., Band, L. E., Belt, K. T., Meyer, P. M., \& Welty, C. (2010). Land use and climate variability amplify contaminant pulses. Eos, Transactions American Geophysical Union, 91(25), 221-222. https://doi.org/10.1029/2010eo250001

Kayranli, B., Scholz, M., Mustafa, A., \& Hedmark, Å. (2010). Carbon storage and fluxes within freshwater wetlands: A critical review. Wetlands, 30(1), 111-124. https://doi.org/10.1007/s13157-009-0003-4

Kirschke, S., Bousquet, P., Ciais, P., Saunois, M., Canadell, J. G., Dlugokencky, E. J., et al. (2013). Three decades of global methane sources and sinks. Nature Geoscience, 6(10), 813-823. https://doi.org/10.1038/ngeo1955

Köppen, W., \& Geiger, G. (1930). Handbuch der klimatologie-gebrüder borntraeger. (Vol. 1). Berlin: Gebruder Borntraeger.

Kroeze, C., \& Seitzinger, S. P. (1998). The impact of land use on $\mathrm{N}_{2} \mathrm{O}$ emissions from watersheds draining into the northeastern Atlantic Ocean and European seas. Environmental Pollution, 102(1), 149-158. https://doi.org/10.1016/s0269-7491(98)80027-4

Kuhn, M., Lundin, E. J., Giesler, R., Johansson, M., \& Karlsson, J. (2018). Emissions from thaw ponds largely offset the carbon sink of northern permafrost wetlands. Scientific Reports, 8(1), 1-7. https://doi.org/10.1038/s41598-018-27770-x

Lal, R. (2008). Carbon sequestration. Philosophical Transactions of the Royal Society B: Biological Sciences, 363(1492), 815-830. https://doi. org/10.1098/rstb.2007.2185

Lehner, B., \& Döll, P. (2004). Development and validation of a global database of lakes, reservoirs and wetlands. Journal of Hydrology, 296(1-4), 1-22. https://doi.org/10.1016/j.jhydrol.2004.03.028

Li, Z., \& Bowman, R. S. (2001). Retention of inorganic oxyanions by organo-kaolinite. Water Research, 35(16), 3771-3776. https://doi. org/10.1016/s0043-1354(01)00120-8

Liu, B., Frostegård, Å., \& Bakken, L. R. (2014). Impaired reduction of $\mathrm{N}_{2} \mathrm{O}$ to $\mathrm{N}_{2}$ in acid soils is due to a posttranscriptional interference with the expression of nosZ. mBio, 5(3). https://doi.org/10.1128/mbio.01383-14

Liu, L., Zhuang, Q., Oh, Y., Shurpali, N. J., Kim, S., \& Poulter, B. (2020). Uncertainty quantification of global net methane emissions from terrestrial ecosystems using a mechanistically based biogeochemistry model. Journal of Geophysical Research: Biogeosciences, 125, e2019JG005428. https://doi.org/10.1029/2019JG005428

Loiko, S. V., Pokrovsky, O. S., Raudina, T. V., Lim, A., Kolesnichenko, L. G., Shirokova, L. S., et al. (2017). Abrupt permafrost collapse enhances organic carbon, $\mathrm{CO}_{2}$, nutrient and metal release into surface waters. Chemical Geology, 471, 153-165. https://doi.org/10.1016/j. chemgeo.2017.10.002

Luke, S., Preston, M. D., Basiliko, N., \& Watmough, S. A. (2015). Microbial communities, biomass, and carbon mineralization in acidic, nutrient-poor peatlands impacted by metal and acid deposition. Water, Air, \& Soil Pollution, 226(2), 19. https://doi.org/10.1007/ s11270-014-2265-6

Maggi, F. (2019). BRTSim, a general-purpose computational solver for hydrological, biogeochemical, and ecosystem dynamics. arXiv preprint arXiv:1903.07015.

Maggi, F., Gu, C., Riley, W., Hornberger, G., Venterea, R., Xu, T., \& Oldenburg, C. (2008). A mechanistic treatment of the dominant soil nitrogen cycling processes: Model development, testing, and application. Journal of Geophysical Research: Biogeosciences, 113 , G02016. https://doi.org/10.1029/2007JG000578

Malone, L., Lacelle, D., Kokelj, S., \& Clark, I. D. (2013). Impacts of hillslope thaw slumps on the geochemistry of permafrost catchments (Stony Creek Watershed, NWT, Canada). Chemical Geology, 356, 38-49. https://doi.org/10.1016/j.chemgeo.2013.07.010

Marzadri, A., Dee, M. M., Tonina, D., Bellin, A., \& Tank, J. L. (2017). Role of surface and subsurface processes in scaling $\mathrm{N}_{2} \mathrm{O}$ emissions along riverine networks. Proceedings of the National Academy of Sciences of the United States of America, 114(17), 4330-4335. https:// doi.org/10.1073/pnas.1617454114

Matías, L., Castro, J., \& Zamora, R. (2011). Soil-nutrient availability under a global-change scenario in a Mediterranean mountain ecosystem. Global Change Biology, 17(4), 1646-1657. https://doi.org/10.1111/j.1365-2486.2010.02338.x

McBratney, A., Field, D. J., \& Koch, A. (2014). The dimensions of soil security. Geoderma, 213, 203-213. https://doi.org/10.1016/j. geoderma.2013.08.013

Mekonnen, Z. A., Grant, R. F., \& Schwalm, C. (2016). Sensitivity of modeled NEP to climate forcing and soil at site and regional scales: Implications for upscaling ecosystem models. Ecological Modelling, 320, 241-257. https://doi.org/10.1016/j.ecolmodel.2015.10.004

Melton, J. R., Wania, R., Hodson, E. L., Poulter, B., Ringeval, B., Spahni, R., et al. (2013). Present state of global wetland extent and wetland methane modelling: Conclusions from a model inter-comparison project (WETCHIMP). Biogeosciences, 10, 753-788. https://doi. org/10.5194/bg-10-753-2013

Meng, L., Hess, P. G. M., Mahowald, N. M., Yavitt, J. B., Riley, W. J., Subin, Z. M., et al. (2012). Sensitivity of wetland methane emissions to model assumptions: Application and model testing against site observations. Biogeosciences, 9(7), 2793-2819. https://doi.org/10.5194/ bg-9-2793-2012

Menne, M. J., Durre, I., Vose, R. S., Gleason, B. E., \& Houston, T. G. (2012). An overview of the global historical climatology network-daily database. Journal of Atmospheric and Oceanic Technology, 29(7), 897-910. https://doi.org/10.1175/jtech-d-11-00103.1

Mitsch, W. J., Bernal, B., Nahlik, A. M., Mander, Ü., Zhang, L., Anderson, C. J., et al. (2013). Wetlands, carbon, and climate change. Landscape Ecology, 28(4), 583-597. https://doi.org/10.1007/s10980-012-9758-8

Mosier, A. R., Morgan, J. A., King, J. Y., Lecain, D., \& Milchunas, D. G. (2002). Soil-atmosphere exchange of $\mathrm{CH}_{4}, \mathrm{CO}_{2}, \mathrm{NO}_{\mathrm{x}}$, and $\mathrm{N}_{2} \mathrm{O}$ in the Colorado shortgrass steppe under elevated $\mathrm{CO}_{2}$. Plant and Soil, 240(2), 201-211. https://doi.org/10.1023/a:1015783801324

Nahlik, A. M., \& Mitsch, W. J. (2010). Methane emissions from created riverine wetlands. Wetlands, 30(4), 783-793. https://doi.org/10.1007/ s13157-010-0038-6

Pangala, S. R., Enrich-Prast, A., Basso, L. S., Peixoto, R. B., Bastviken, D., Hornibrook, E. R. C., et al. (2017). Large emissions from floodplain trees close the amazon methane budget. Nature, 552(7684), 230-234. https://doi.org/10.1038/nature24639 
Pastorello, G., Trotta, C., Canfora, E., Chu, H., Christianson, D., Cheah, Y.-W., et al. (2020). The FLUXNET2015 dataset and the ONEFlux processing pipeline for eddy covariance data. Scientific Data, 7(1), 1-27.

Pasut, C., Tang, F. H., \& Maggi, F. (2020). A mechanistic analysis of wetland biogeochemistry in response to temperature, vegetation, and nutrient input changes. Journal of Geophysical Research: Biogeosciences, 125, e2019JG005437. https://doi.org/10.1029/2019JG005437

Paul, E. A. (2014). Soil microbiology, ecology and biochemistry. Academic Press.

Pei, G., Liu, J., Peng, B., Gao, D., Wang, C., Dai, W., et al. (2019). Nitrogen, lignin, C/N as important regulators of gross nitrogen release and immobilization during litter decomposition in a temperate forest ecosystem. Forest Ecology and Management, 440, 61-69. https:// doi.org/10.1016/j.foreco.2019.03.001

Petrescu, A., Van Beek, L., Van Huissteden, J., Prigent, C., Sachs, T., Corradi, C., \& Dolman, A. (2010). Modeling regional to global $\mathrm{CH}_{4}$ emissions of boreal and arctic wetlands. Global Biogeochemical Cycles, 24, GB4009. https://doi.org/10.1029/2009GB003610

Potter, P., Ramankutty, N., Bennett, E., \& Donner, S. (2011a). Global fertilizer and manure, version 1: Nitrogen fertilizer application. Palisades, NY: NASA Socioeconomic Data and Applications Center (SEDAC).

Potter, P., Ramankutty, N., Bennett, E., \& Donner, S. (2011b). Global fertilizer and manure, version 1: Phosphorus fertilizer application. Palisades, NY: NASA Socioeconomic Data and Applications Center (SEDAC).

Poulter, B., Bousquet, P., Canadell, J. G., Ciais, P., Peregon, A., Saunois, M., et al. (2017). Global wetland contribution to 2000-2012 atmospheric methane growth rate dynamics. Environmental Research Letters, 12(9), 094013. https://doi.org/10.1088/1748-9326/aa8391

Reis, V., Hermoso, V., Hamilton, S. K., Ward, D., Fluet-Chouinard, E., Lehner, B., \& Linke, S. (2017). A global assessment of inland wetland conservation status. BioScience, 67(6), 523-533. https://doi.org/10.1093/biosci/bix045

Riley, W. J., Maggi, F., Kleber, M., Torn, M. S., Tang, J. Y., Dwivedi, D., \& Guerry, N. (2014). Long residence times of rapidly decomposable soil organic matter: Application of a multi-phase, multi-component, and vertically resolved model (BAMS1) to soil carbon dynamics. Geoscientific Model Development, 7(4), 1335-1355. https://doi.org/10.5194/gmd-7-1335-2014

Riley, W. J., Subin, Z. M., Lawrence, D. M., Swenson, S. C., Torn, M. S., Meng, L., et al. (2011). Barriers to predicting changes in global terrestrial methane fluxes: Analyses using CLM4Me, a methane biogeochemistry model integrated in CESM. Biogeosciences, 8(7), 1925-1953. https://doi.org/10.5194/bg-8-1925-2011

Rohli, R. V., Joyner, T. A., Reynolds, S. J., \& Ballinger, T. J. (2015). Overlap of global Köppen-Geiger climates, biomes, and soil orders. Physical Geography, 36(2), 158-175. https://doi.org/10.1080/02723646.2015.1016384

Rouifed, S., Handa, I. T., David, J.-F., \& Hättenschwiler, S. (2010). The importance of biotic factors in predicting global change effects on decomposition of temperate forest leaf litter. Oecologia, 163(1), 247-256. https://doi.org/10.1007/s00442-009-1528-1

Saunois, M., Stavert, A. R., Poulter, B., Bousquet, P., Canadell, J. G., Jackson, R. B., \& others (2020). The Global Methane Budget 2000-2017. Earth System Science Data, 12(3), 1561-1623.

Schroeder, R., McDonald, K., Chapman, B., Jensen, K., Podest, E., Tessler, Z., et al. (2015). Development and evaluation of a multi-year fractional surface water data set derived from active/passive microwave remote sensing data. Remote Sensing, 7(12), 16688-16732. https://doi.org/10.3390/rs71215843

Shannon, R. D., \& White, J. R. (1994). A three-year study of controls on methane emissions from two Michigan peatlands. Biogeochemistry, 27(1), 35-60. https://doi.org/10.1007/bf00002570

Snowdon, P., Ryan, P., \& Raison, R. J. (2005). Review of C:N ratios in vegetation, litter and soil under Australian native forests and plantations. CSIRO Research Publications Repository.

Solomon, S. (2007). The physical science basis: Contribution of Working Group I to the fourth assessment report of the Intergovernmental Panel on Climate Change. Intergovernmental Panel on Climate Change (IPCC). Climate Change, 2007, 996.

Sulla-Menashe, D., Gray, J. M., Abercrombie, S. P., \& Friedl, M. A. (2019). Hierarchical mapping of annual global land cover 2001 to present: The MODIS collection 6 land cover product. Remote Sensing of Environment, 222, 183-194. https://doi.org/10.1016/j.rse.2018.12.013

Tang, F. H. M., Riley, W. J., \& Maggi, F. (2019). Hourly and daily rainfall intensification causes opposing effects on C and N emissions, storage, and leaching in dry and wet grasslands. Biogeochemistry, 144(2), 197-214. https://doi.org/10.1007/s10533-019-00580-7

Tian, H., Chen, G., Lu, C., Xu, X., Ren, W., Zhang, B., et al. (2015). Global methane and nitrous oxide emissions from terrestrial ecosystems due to multiple environmental changes. Ecosystem Health and Sustainability, 1(1), 1-20. https://doi.org/10.1890/ehs14-0015.1

Tian, H., Melillo, J., Lu, C., Kicklighter, D., Liu, M., Ren, W., et al. (2011). China's terrestrial carbon balance: Contributions from multiple global change factors. Global Biogeochemical Cycles, 25, GB1007. https://doi.org/10.1029/2010GB003838

Tian, H., Xu, X., Lu, C., Liu, M., Ren, W., Chen, G., \& Liu, J. (2011). Net exchanges of $\mathrm{CO}_{2}$, $\mathrm{CH}_{4}$, and $\mathrm{N}_{2} \mathrm{O}$ between China's terrestrial ecosystems and the atmosphere and their contributions to global climate warming. Journal of Geophysical Research: Biogeosciences, 116 , G02011. https://doi.org/10.1029/2010JG001393

Treat, C. C., Wollheim, W. M., Varner, R. K., \& Bowden, W. B. (2016). Longer thaw seasons increase nitrogen availability for leaching during fall in tundra soils. Environmental Research Letters, 11(6), 064013. https://doi.org/10.1088/1748-9326/11/6/064013

Turner, P. A., Griffis, T. J., Lee, X., Baker, J. M., Venterea, R. T., \& Wood, J. D. (2015). Indirect nitrous oxide emissions from streams within the US corn belt scale with stream order. Proceedings of the National Academy of Sciences of the United States of America, 112(32), 9839-9843. https://doi.org/10.1073/pnas.1503598112

Verhoeven, J., Arheimer, B., Yin, C., \& Hefting, M. (2006). Regional and global concerns over wetlands and water quality. Trends in Ecology \& Evolution, 21(2), 96-103. https://doi.org/10.1016/j.tree.2005.11.015

Villa, J. A., \& Bernal, B. (2018). Carbon sequestration in wetlands, from science to practice: An overview of the biogeochemical process, measurement methods, and policy framework. Ecological Engineering, 114, 115-128. https://doi.org/10.1016/j.ecoleng.2017.06.037

Vitousek, P. M., Aber, J. D., Howarth, R. W., Likens, G. E., Matson, P. A., Schindler, D. W., et al. (1997). Human alteration of the global nitrogen cycle: Sources and consequences. Ecological Applications, 7(3), 737-750. https://doi.org/10.1890/1051-0761(1997)007[0737 :haotgn]2.0.co;2

Wagner, L., Vidon, P., Tedesco, L., \& Gray, M. (2008). Stream nitrate and doc dynamics during three spring storms across land uses in glaciated landscapes of the midwest. Journal of Hydrology, 362(3-4), 177-190. https://doi.org/10.1016/j.jhydrol.2008.08.013

Walter, B. P., Heimann, M., \& Matthews, E. (2001). Modeling modern methane emissions from natural wetlands: 1. Model description and results. Journal of Geophysical Research, 106(D24), 34189-34206. https://doi.org/10.1029/2001jd900165

Wania, R., Melton, J. R., Hodson, E. L., Poulter, B., Ringeval, B., Spahni, R., et al. (2013). Present state of global wetland extent and wetland methane modeling: Methodology of a model inter-comparison project (WETCHIMP). Geoscientific Model Development, 6(3), 617-641. https://doi.org/10.5194/gmd-6-617-2013

Were, D., Kansiime, F., Fetahi, T., Cooper, A., \& Jjuuko, C. (2019). Carbon sequestration by wetlands: A critical review of enhancement measures for climate change mitigation. Earth Systems and Environment, 3, 327-340.

Whitehead, D. (2000). Nutrient elements in grassland: Soil-plant-animal relationships. CABI Publishing. 
Woodward, F. I., Smith, T. M., \& Emanuel, W. R. (1995). A global land primary productivity and phytogeography model. Global Biogeochemical Cycles, 9(4), 471-490. https://doi.org/10.1029/95gb02432

Xu, X., Tian, H., Zhang, C., Liu, M., Ren, W., Chen, G., \& Bruhwiler, L. (2010). Attribution of spatial and temporal variations in terrestrial methane flux over North America. Biogeosciences Discussions, 7(4). https://doi.org/10.5194/bg-7-3637-2010

Zhang, Y., Pena Arancibia, J., McVicar, T., Chiew, F., Vaze, J., Zheng, H., \& Wang, Y. (2016). Monthly global observation-driven Penman-Monteith-Leuning (PML) evapotranspiration and components (v2). CSIRO. Data Collection. https://doi.org/10.4225/08/5719A5C48DB85

Zhu, Q., Peng, C., Chen, H., Fang, X., Liu, J., Jiang, H., et al. (2015). Estimating global natural wetland methane emissions using process modelling: Spatio-temporal patterns and contributions to atmospheric methane fluctuations. Global Ecology and Biogeography, 24(8), 959-972. https://doi.org/10.1111/geb.12307 